\title{
LEVEL II SCOUR ANALYSIS FOR BRIDGE 7 (ANDOTH00010007) on TOWN HIGHWAY 1 (FAS 132), crossing ANDOVER BRANCH, ANDOVER, VERMONT
}

U.S. Geological Survey Open-File Report 97-186

Prepared in cooperation with

VERMONT AGENCY OF TRANSPORTATION and

FEDERAL HIGHWAY ADMINISTRATION 


\section{LEVEL II SCOUR ANALYSIS FOR BRIDGE 7 (ANDOTH00010007) on TOWN HIGHWAY 1 (FAS 132), crossing ANDOVER BRANCH, ANDOVER, VERMONT \\ By ROBERT H. FLYNN}

U.S. Geological Survey Open-File Report 97-186

Prepared in cooperation with

VERMONT AGENCY OF TRANSPORTATION

and

FEDERAL HIGHWAY ADMINISTRATION 


\title{
U.S. DEPARTMENT OF THE INTERIOR BRUCE BABBITT, Secretary
}

\author{
U.S. GEOLOGICAL SURVEY \\ Gordon P. Eaton, Director
}

For additional information write to:

District Chief

U.S. Geological Survey 361 Commerce Way

Pembroke, NH 03275-3718
Copies of this report may be purchased from:

U.S. Geological Survey

Branch of Information Services

Open-File Reports Unit

Box 25286

Denver, CO 80225-0286 


\section{CONTENTS}

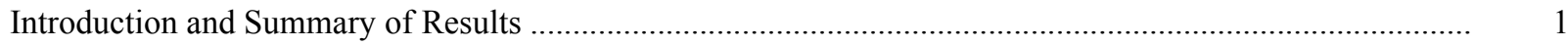

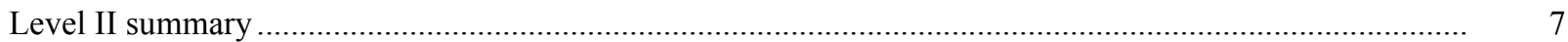

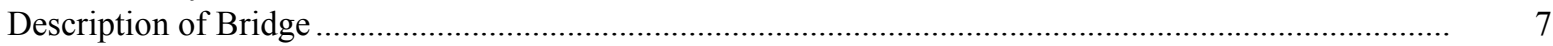

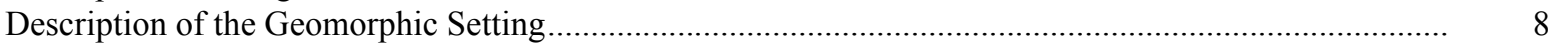

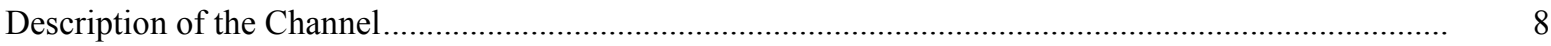

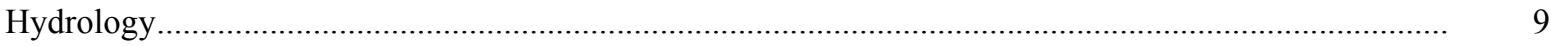

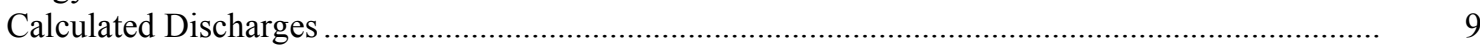

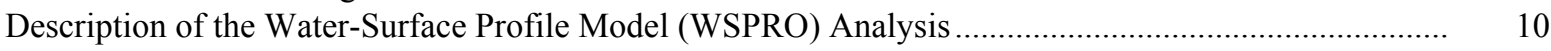

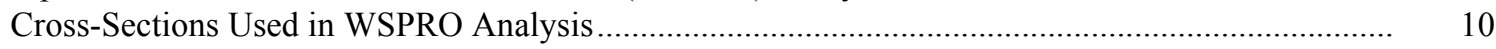

Data and Assumptions Used in WSPRO Model ...................................................................... 11

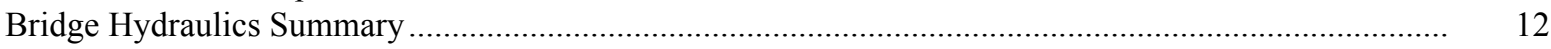

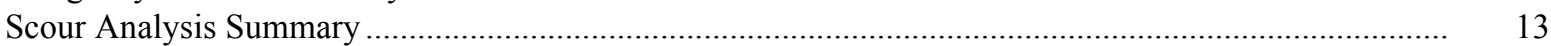

Special Conditions or Assumptions Made in Scour Analysis ...................................................... 13

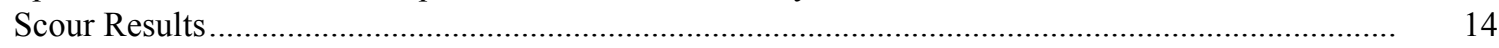

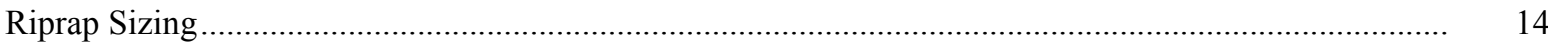

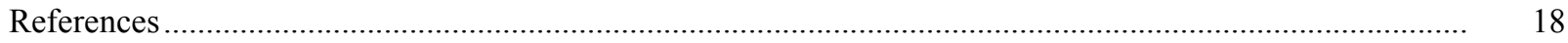

Appendixes:

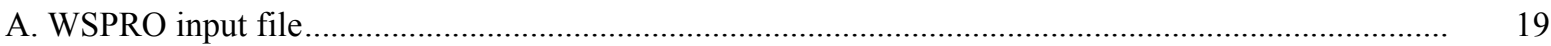

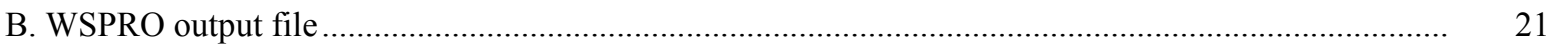

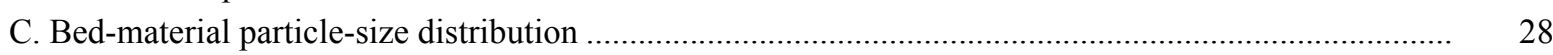

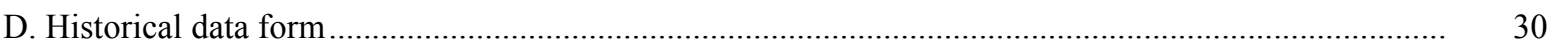

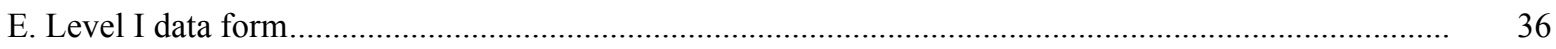

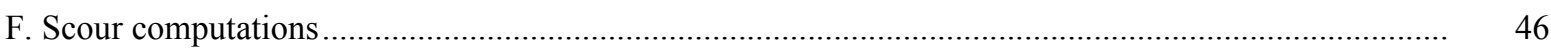

\section{FIGURES}

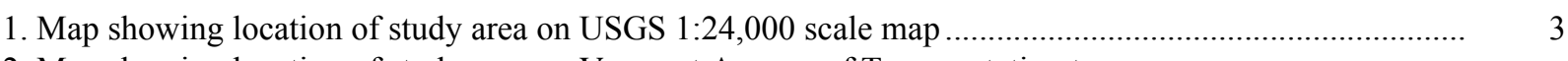

2. Map showing location of study area on Vermont Agency of Transportation town
highway map

3. Structure ANDOTH00010007 viewed from upstream (August 28, 1996) ….......................................... 5

4. Downstream channel viewed from structure ANDOTH00010007 (August 28, 1996). .......................... 5

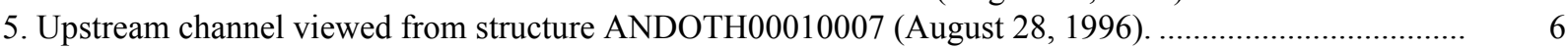

6. Structure ANDOTH00010007 viewed from downstream (August 28, 1996)..................................... 6

7. Water-surface profiles for the 100- and 500-year discharges at structure

ANDOTH00010007 on Town Highway 1, crossing Andover Branch,

Andover, Vermont.

8. Scour elevations for the 100- and 500-year discharges at structure

ANDOTH00010007 on Town Highway 1, crossing Andover Branch,

Andover, Vermont.

\section{TABLES}

1. Remaining footing/pile depth at abutments for the 100-year discharge at structure

ANDOTH00010007 on Town Highway 1, crossing Andover Branch,

Andover, Vermont

2. Remaining footing/pile depth at abutments for the 500-year discharge at structure

ANDOTH00010007 on Town Highway 1, crossing Andover Branch,

Andover, Vermont 


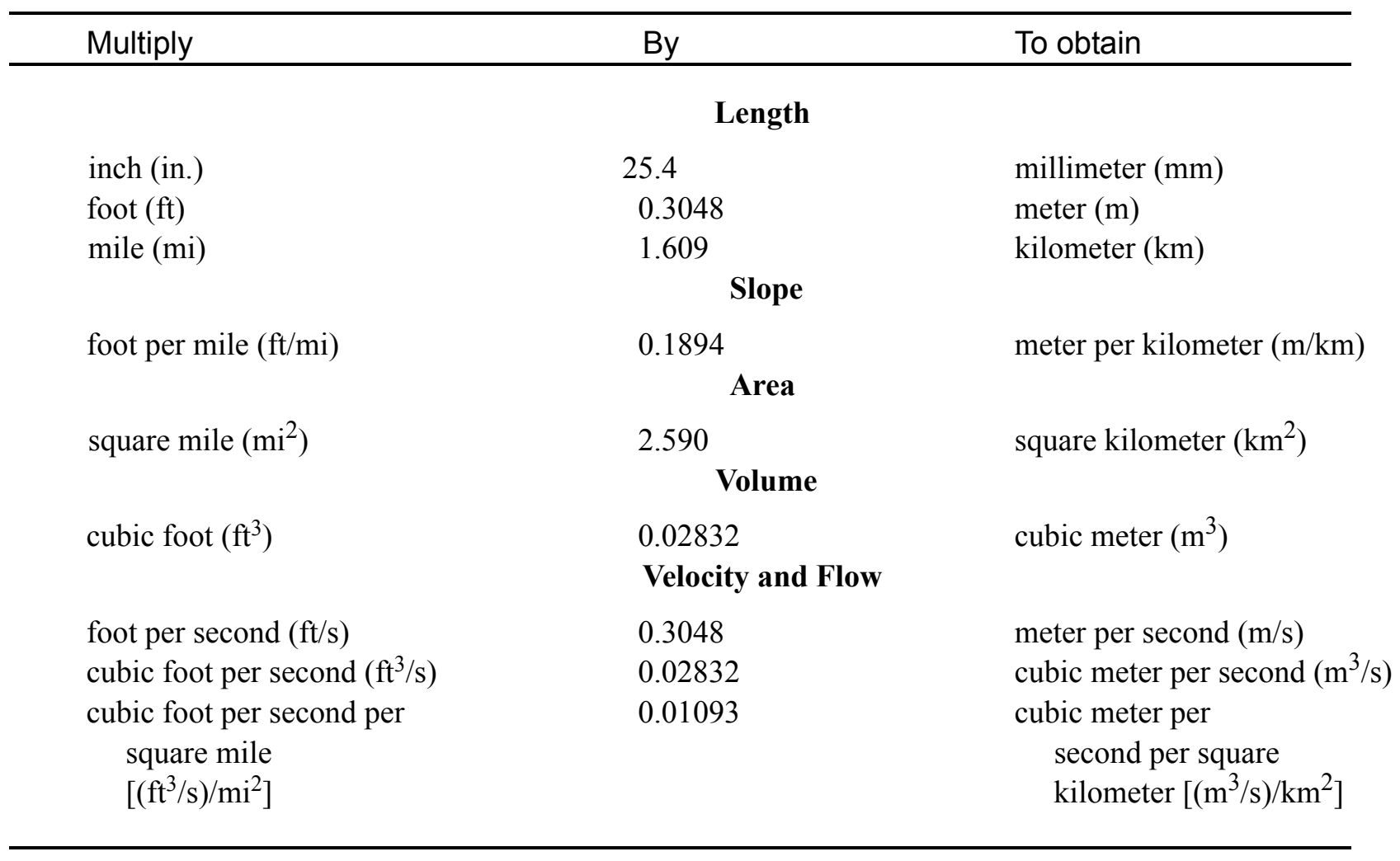

\section{OTHER ABBREVIATIONS}

$\begin{array}{lrlr}\mathrm{BF} & \text { bank full } & \text { LWW } & \text { left wingwall } \\ \mathrm{cfs} & \text { cubic feet per second } & \text { MC } & \text { main channel } \\ \mathrm{D}_{50} & \text { median diameter of bed material } & \text { RAB } & \text { right abutment } \\ \mathrm{DS} & \text { downstream } & \text { RABUT } & \text { face of right abutment } \\ \mathrm{elev} & \text { elevation } & \text { RB } & \text { right bank } \\ \mathrm{f} / \mathrm{p} & \text { flood plain } & \text { ROB } & \text { right overbank } \\ \mathrm{ft}^{2} & \text { square feet } & \text { RWW } & \text { right wingwall } \\ \mathrm{ft} / \mathrm{ft} & \text { feet per foot } & \text { TH } & \text { town highway } \\ \mathrm{JCT} & \text { junction } & \text { UB } & \text { under bridge } \\ \mathrm{LAB} & \text { left abutment } & \text { US } & \text { upstream } \\ \mathrm{LABUT} & \text { face of left abutment } & \text { USGS } & \text { United States Geological Survey } \\ \mathrm{LB} & \text { left bank } & \text { VTAOT Vermont Agency of Transportation } \\ \mathrm{LOB} & \text { left overbank } & \text { WSPRO } & \text { water-surface profile model }\end{array}$

In this report, the words "right" and "left" refer to directions that would be reported by an observer facing downstream. Sea level: In this report, "sea level" refers to the National Geodetic Vertical Datum of 1929-- a geodetic datum derived from a general adjustment of the first-order level nets of the United States and Canada, formerly called Sea Level Datum of 1929.

In the appendices, the above abbreviations may be combined. For example, USLB would represent upstream left bank. 


\title{
LEVEL II SCOUR ANALYSIS FOR BRIDGE 7 (ANDOTH00010007) ON TOWN HIGHWAY 1 (FAS 132), CROSSING ANDOVER BRANCH, ANDOVER, VERMONT
}

\author{
By Robert H. Flynn
}

\section{INTRODUCTION AND SUMMARY OF RESULTS}

This report provides the results of a detailed Level II analysis of scour potential at structure ANDOTH00010007 on Town Highway 1 crossing Andover Branch, Andover, Vermont (figures 1-8). A Level II study is a basic engineering analysis of the site, including a quantitative analysis of stream stability and scour (U.S. Department of Transportation, 1993). Results of a Level I scour investigation also are included in Appendix E of this report. A Level I investigation provides a qualitative geomorphic characterization of the study site. Information on the bridge, gleaned from Vermont Agency of Transportation (VTAOT) files, was compiled prior to conducting Level I and Level II analyses and is found in Appendix D.

The site is in the Green Mountain section of the New England physiographic province in southern Vermont. The $7.21-\mathrm{mi}^{2}$ drainage area is in a predominantly rural and forested basin. In the vicinity of the study site, the surface cover is pasture upstream of the bridge while the immediate banks have dense woody vegetation. Downstream of the bridge, the banks and overbanks are forested.

In the study area, Andover Branch has an incised, sinuous channel with a slope of approximately $0.02 \mathrm{ft} / \mathrm{ft}$, an average channel top width of $45 \mathrm{ft}$ and an average bank height of $5 \mathrm{ft}$. The channel bed material ranges from gravel to boulder with a median grain size $\left(\mathrm{D}_{50}\right)$ of $58.0 \mathrm{~mm}(0.19 \mathrm{ft})$. The geomorphic assessment at the time of the Level I and Level II site visit on August 28, 1996, indicated that the reach was laterally unstable due to evidence of lateral movement of the channel 200 feet upstream along the left bank and near the bridge along the right bank.

The Town Highway 1 crossing of Andover Branch is a 32-ft-long, two-lane bridge consisting of one 29-foot concrete slab span (Vermont Agency of Transportation, written communication, March 28, 1995). The bridge is supported by vertical, concrete abutments with wingwalls. The channel is skewed approximately 10 degrees to the opening while the opening-skew-to-roadway is 0 degrees. 
The scour protection measures at the site included type- 2 stone fill (less than 36 inches diameter) along the entire base length of the upstream wingwalls and type- 3 stone fill (less than 48 inches diameter) along the entire base length of the downstream wingwalls and the right abutment. Additional details describing conditions at the site are included in the Level II Summary and Appendices $\mathrm{D}$ and $\mathrm{E}$.

Scour depths and rock rip-rap sizes were computed using the general guidelines described in Hydraulic Engineering Circular 18 (Richardson and others, 1995). Total scour at a highway crossing is comprised of three components: 1) long-term streambed degradation; 2) contraction scour (due to accelerated flow caused by a reduction in flow area at a bridge) and; 3) local scour (caused by accelerated flow around piers and abutments). Total scour is the sum of the three components. Equations are available to compute depths for contraction and local scour and a summary of the results of these computations follows.

Contraction scour for all modelled flows ranged from 0.0 to $1.6 \mathrm{ft}$. The worst-case contraction scour occurred at the 100-year discharge. Abutment scour ranged from 7.1 to $10.7 \mathrm{ft}$ at the right abutment with the worst-case abutment scour occurring at the 500 -year discharge. Abutment scour ranged from 7.5 to $8.3 \mathrm{ft}$ at the left abutment with the worst-case abutment scour occurring at the incipient road overtopping discharge. Additional information on scour depths and depths to armoring are included in the section titled "Scour Results". Scoured-streambed elevations, based on the calculated scour depths, are presented in tables 1 and 2. A cross-section of the scour computed at the bridge is presented in figure 8. Scour depths were calculated assuming an infinite depth of erosive material and a homogeneous particle-size distribution.

It is generally accepted that the Froehlich equation (abutment scour) gives "excessively conservative estimates of scour depths" (Richardson and others, 1995, p. 46). Usually, computed scour depths are evaluated in combination with other information including (but not limited to) historical performance during flood events, the geomorphic stability assessment, existing scour protection measures, and the results of the hydraulic analyses. Therefore, scour depths adopted by VTAOT may differ from the computed values documented herein. 


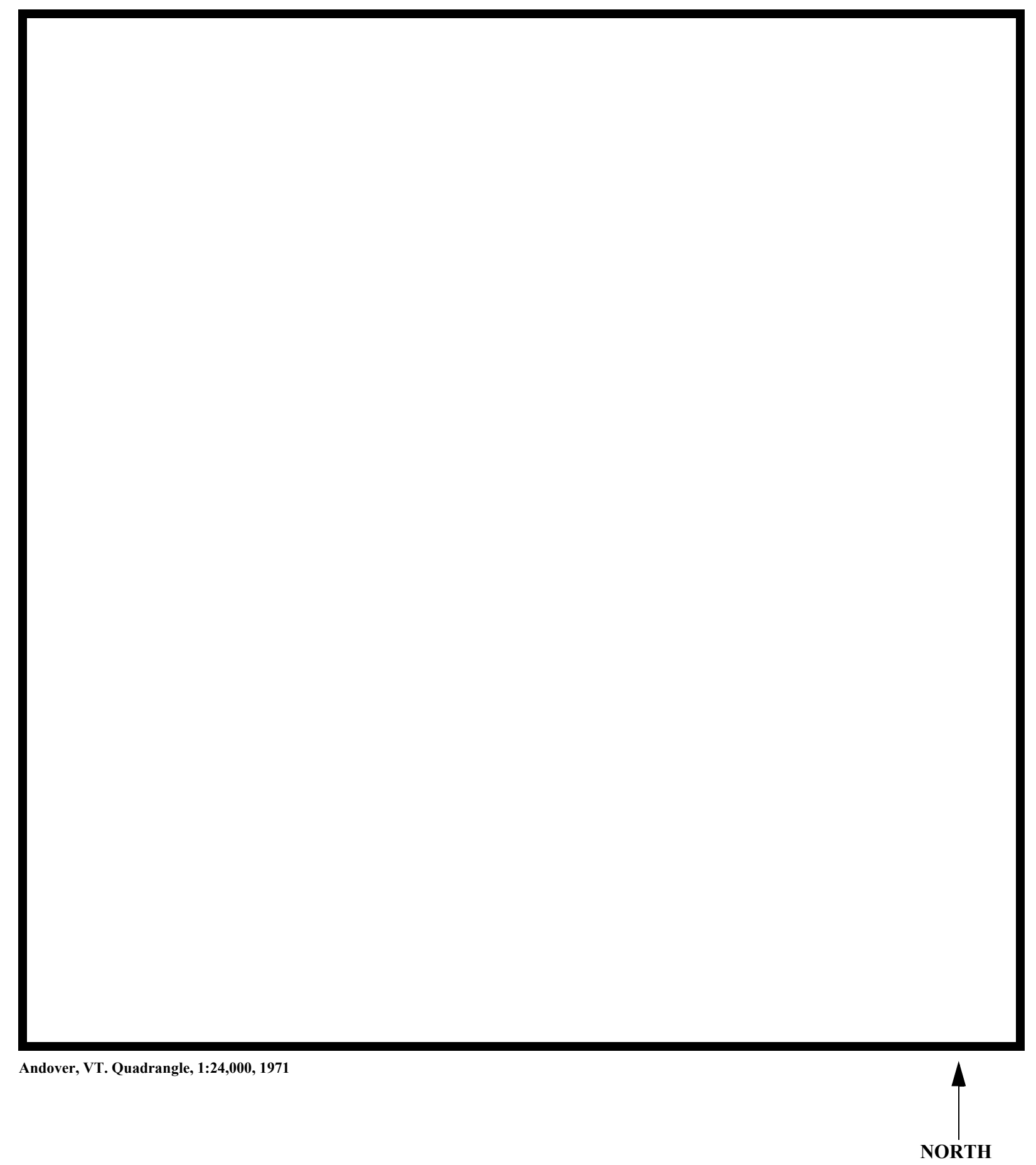

Figure 1. Location of study area on USGS 1:24,000 scale map. 
Figure 2. Location of study area on Vermont Agency of Transportation town highway map. 

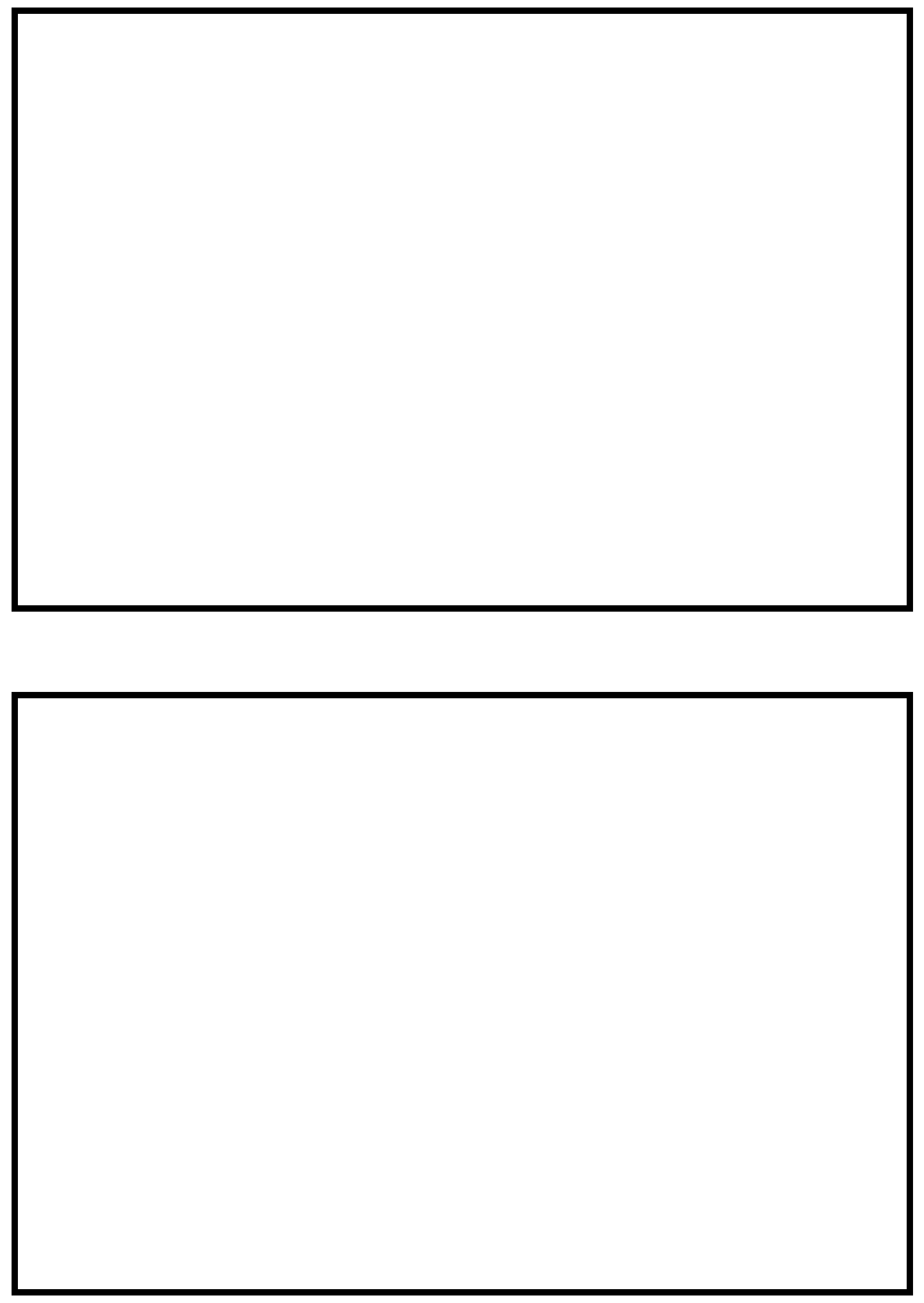

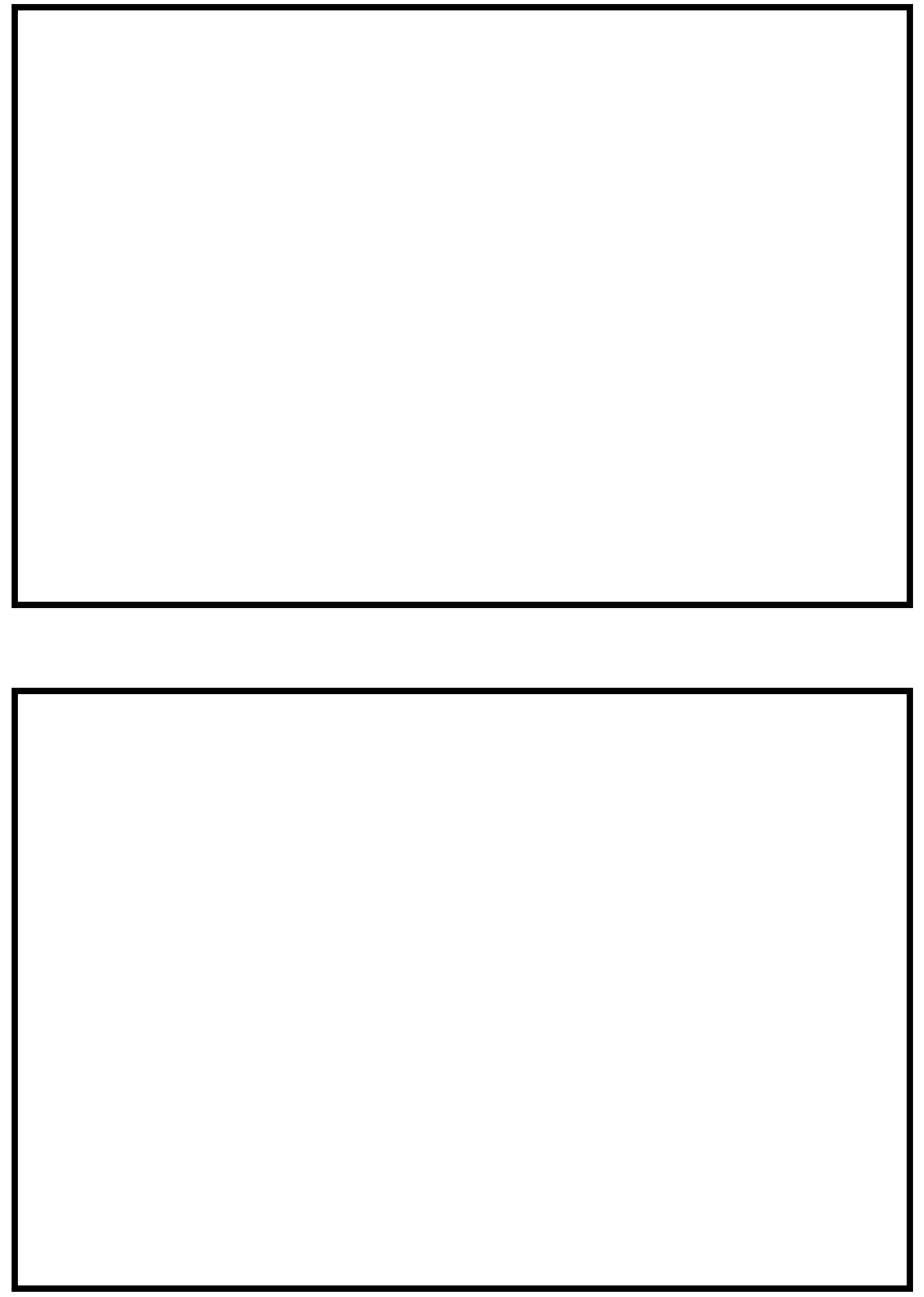


\section{LEVEL II SUMMARY}

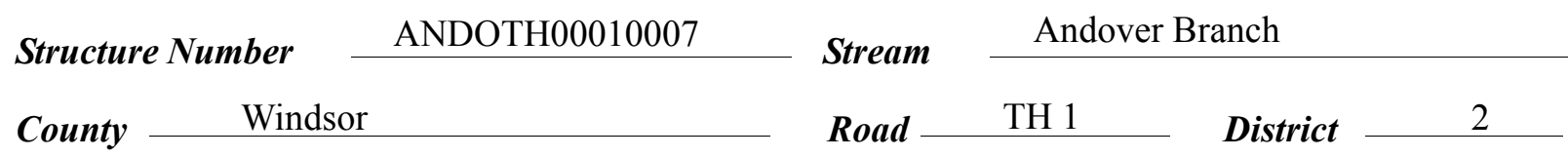

\section{Description of Bridge}

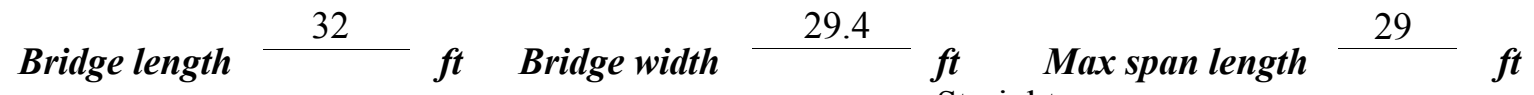
Alignment of bridge to road (on curve or straight)

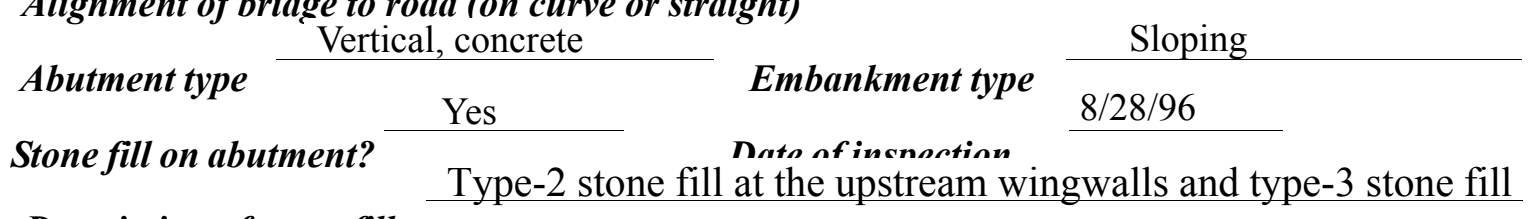
Dasanintion af atann fill Type-2 stone fill at the upstream wingwalls and type-3 stone fill at the downstream wingwalls and along the right abutment in good condition.

Abutments and wingwalls are concrete.

Y

$10 \quad \underline{\mathrm{N}}$

Is bridge skewed to flood flow according to There' 'survey? Angle are severe channel bends $200 \mathrm{ft}$ upstream and $230 \mathrm{ft}$ downstream of the bridge.

Debris accumulation on bridge at time of Level I or Level II site visit:

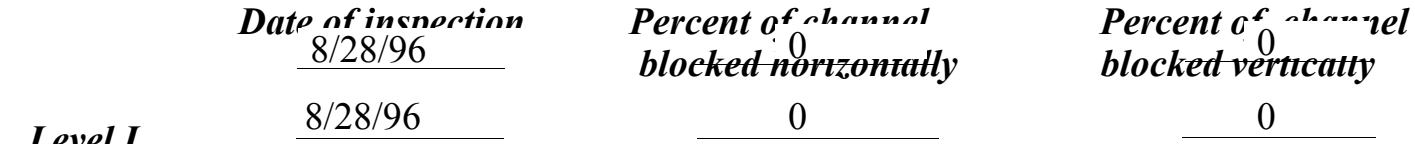

Level II Moderate. The channel is laterally unstable and sinuous with tree cover along the upstream channel banks.

Potential for debris

There is a point bar along the left abutment. 8/28/96

Dosrriho any, fonturos noar ar at tho hridoo that mav affort flow, (includo ahsorvation dato) 


\section{Description of the Geomorphic Setting}

General topography The channel is located within a moderate relief valley setting with a narrow flood plain and steep valley walls on both sides.

Geomorphic conditions at bridge site: downstream (DS), upstream (US)

Date of inspection $\quad 8 / 28 / 96$

DS left: $\quad$ Moderately sloped overbank to steep valley wall

DS right: Moderately sloped overbank to steep valley wall

US left: $\quad$ Moderately sloped overbank

US right: $\quad$ Moderately sloped overbank

\section{Description of the Channel}

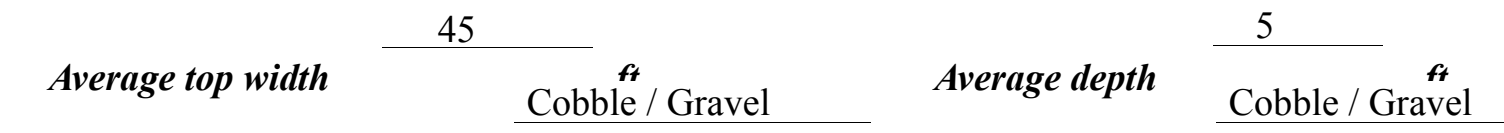

Predominant bed material

Bank material

Sinuous and laterally

unstable with semi-alluvial channel boundaries and a narrow flood plain.

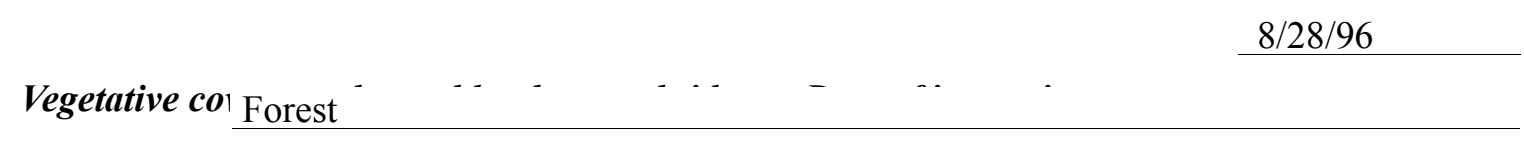

DS left: $\quad$ Forest

DS right: $\quad$ Grass and forest

US left: $\quad$ Meadow and forest

US right:

$\mathrm{N}$

Do banks appear stable? There is evidence of lateral movement of the channel 200 feet waw upstream along the left bank and near the bridge along the right bank. 8/28/96
date of observatton.

None. $8 / 28 / 96$

Describe any obstructions in channel and date of observation. 


\section{Hydrology}

Drainage area $\stackrel{7.21}{\longrightarrow} \mathbf{m i}^{2}$

Percentage of drainage area in physiographic provinces: (approximate)

Physiographic province/section

New England / Green Mountain
Percent of drainage area 100

Is drainage area considered rural or urban? Rural Describe any significant urbanization:

Is there a USGS gage on the stream of interest?

No

$-$

\section{USGS gage description}

USGS gage number

Gage drainage area $m i^{2}$

No

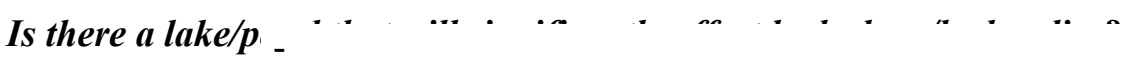

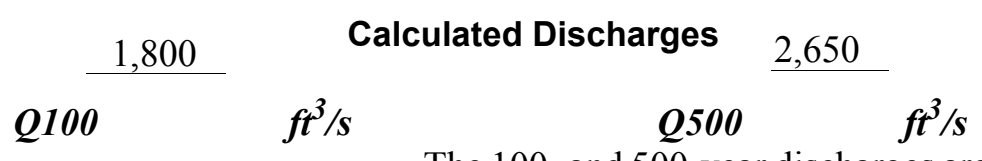

The 100- and 500-year discharges are based on flood

frequency estimates available from the VTAOT database. These values were selected due to the central tendency of the discharge frequency curve with others which were developed from empirical relationships and extended to the 500-year discharge (Benson, 1962; Johnson and Tasker, 1974; FHWA, 1983; Potter, 1957a\&b; Talbot, 1887). 


\section{Description of the Water-Surface Profile Model (WSPRO) Analysis}

Datum for WSPRO analysis (USGS survey, sea level, VTAOT plans)

USGS survey

Datum tie between USGS survey and VTAOT plans

Subtract $0.2 \mathrm{ft}$ from arbitrary

survey datum to obtain VTAOT plans' datum.

Description of reference marks used to determine USGS datum. $\quad$ RM1 is a chiseled X on

top of the upstream end of the left abutment (elev. $499.71 \mathrm{ft}$, arbitrary survey datum). RM2 is a

chiseled X on top of the downstream end of the right abutment (elev. $499.69 \mathrm{ft}$, arbitrary survey

datum).

\section{Cross-Sections Used in WSPRO Analysis}

\begin{tabular}{cccl}
\hline${ }^{1}$ Cross-section & $\begin{array}{c}\text { Section } \\
\text { Reference } \\
\text { Distance } \\
(\text { SRD) } \text { in feet }\end{array}$ & $\begin{array}{c}{ }^{2} \text { Cross-section } \\
\text { development }\end{array}$ & \multicolumn{1}{c}{ Comments } \\
\hline EXITX & -27 & 1 & $\begin{array}{l}\text { Exit section } \\
\text { Downstream Full-valley } \\
\text { section (Templated from } \\
\text { FULLV }\end{array}$ \\
BRIDG & 0 & 2 & $\begin{array}{l}\text { BXitX) } \\
\text { Bridge section } \\
\text { RDWAY }\end{array}$ \\
APPRO & 16 & 1 & $\begin{array}{l}\text { Road Grade section } \\
\text { Modelled Approach sec- } \\
\text { tion (as surveyed) }\end{array}$ \\
\hline
\end{tabular}

${ }^{1}$ For location of cross-sections see plan-view sketch included with Level I field form, Appendix E.

For more detail on how cross-sections were developed see WSPRO input file. 


\section{Data and Assumptions Used in WSPRO Model}

Hydraulic analyses of the reach were done by use of the Federal Highway Administration's WSPRO step-backwater computer program (Shearman and others, 1986, and Shearman, 1990). The analyses reported herein reflect conditions existing at the site at the time of the study. Furthermore, in the development of the model it was necessary to assume no accumulation of debris or ice at the site. Results of the hydraulic model are presented in the Bridge Hydraulic Summary, Appendix B, and figure 7.

Channel roughness factors (Manning's " $n$ ") used in the hydraulic model were estimated using field inspections at each cross section following the general guidelines described by Arcement and Schneider (1989). Final adjustments to the values were made during the modelling of the reach. Channel " $\mathrm{n}$ " values for the reach ranged from 0.040 to 0.050 , and overbank " $n$ " values ranged from 0.040 to 0.065 .

Normal depth at the exit section (EXITX) was assumed as the starting water surface. This depth was computed by use of the slope-conveyance method outlined in the user's manual for WSPRO (Shearman, 1990). The slope used was $0.0167 \mathrm{ft} / \mathrm{ft}$ which was estimated from the topographic map (U.S. Geological Survey, 1971).

The surveyed approach section (APPRO) was located one bridge length upstream of the upstream face as recommended by Shearman and others (1986). This location also provides a consistent method for determining scour variables.

For the 100-year discharge, WSPRO assumes critical depth at the bridge section. A supercritical model was developed for this discharge. Analyzing both the supercritical and subcritical profiles, it was determined that the water surface profile does pass through critical depth within the bridge opening. Thus, the assumptions of critical depth at the bridge is a satisfactory solution. 


\section{Bridge Hydraulics Summary}

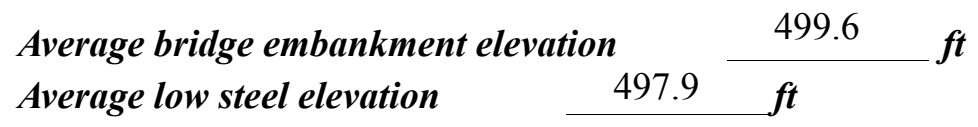

$$
\text { 100-year discharge } \quad 1,800 \quad \mathrm{ft}^{3} / \mathrm{s}
$$

Water-surface elevation in bridge opening $\quad 494.2 \quad f t$

Road overtopping? ___ N Discharge over road ___ -- $\mathrm{ft}^{3} / \mathrm{s}$

Area of flow in bridge opening $\quad 142 \quad \mathrm{ft}^{2}$

Average velocity in bridge opening $12.7 \quad \mathrm{ft} / \mathrm{s}$

Maximum WSPRO tube velocity at bridge $\quad 15.4 \mathrm{ft} / \mathrm{s}$

Water-surface elevation at Approach section with bridge 497.2

Water-surface elevation at Approach section without bridge $\quad 495.3$

Amount of backwater caused by bridge $\quad 1.9$ it

500-year discharge $\quad 2,650 \quad \mathrm{ft}^{3} / \mathrm{s}$

Water-surface elevation in bridge opening $\quad 498.0 \mathrm{ft}$

Road overtopping? ___ Y Discharge over road _ $144.0 \quad \mathrm{ft}^{3} / \mathrm{s}$

Area of flow in bridge opening $\quad 247 \quad \mathrm{ft}^{2}$

Average velocity in bridge opening $8.8 \mathrm{ft} / \mathrm{s}$

Maximum WSPRO tube velocity at bridge 10.5 , 's

Water-surface elevation at Approach section with bridge 500.6

Water-surface elevation at Approach section without bridge $\quad 496.4$

Amount of backwater caused by bridge 4.2 .

Incipient overtopping discharge $\quad 2,170 \quad \mathrm{ft}^{3} / \mathrm{s}$

Water-surface elevation in bridge opening $499.6 \quad t$

$\begin{array}{llll}\text { Area of flow in bridge opening } & 769 & \boldsymbol{f t}^{2} \\ \text { Average velocity in bridge opening } & 2.8 \quad \mathrm{ft} / \mathrm{s}\end{array}$

Maximum WSPRO tube velocity at bridge $\quad 4.4 \quad \mathrm{ft} / \mathrm{s}$

Water-surface elevation at Approach section with bridge 499.6.

Water-surface elevation at Approach section without bridge $\quad 405.8$

Amount of backwater caused by bridge $\quad 3.8 \quad$ it 


\section{Scour Analysis Summary}

\section{Special Conditions or Assumptions Made in Scour Analysis}

Scour depths were computed using the general guidelines described in Hydraulic Engineering Circular 18 (Richardson and others, 1995). Scour depths were calculated assuming an infinite depth of erosive material and a homogeneous particle-size distribution. The results of the scour analysis are presented in tables 1 and 2 and a graph of the scour depths is presented in figure 8 .

Contraction scour for the 100-year discharge model was computed by use of the clear-water contraction scour equation (Richardson and others, 1995, p. 32, equation 20) . The 500-year discharge and incipient road-overflow models resulted in unsubmerged orifice flow. Contraction scour at bridges with orifice flow is best estimated by use of the Chang pressure-flow scour equation (oral communication, J. Sterling Jones, October 4, 1996). Thus, the Chang equation (Richardson and others, 1995, pp. 145-146) was applied to compute the contraction scour for the 500-year and incipient road-overflow discharge. The results of Laursen's clear-water contraction scour were also computed for these discharges and can be found in appendix F. The 100-year discharge model resulted in the worst case contraction scour with a scour depth of $1.6 \mathrm{ft}$. However, it was not the worst case total scour. The computed depths to streambed armoring suggest armoring will not limit the depth of contraction scour.

Abutment scour at the left abutment was computed by use of the Froehlich equation (Richardson and others, 1995, p. 48, equation 28). Variables for the Froehlich equation include the Froude number of the flow approaching the embankments, the length of the embankment blocking flow, and the depth of flow approaching the embankment less any roadway overtopping.

Scour at the right abutment was computed by use of the HIRE equation (Richardson and others, 1995, p. 49, equation 29). The HIRE equation is recommended when the length to depth ratio of the embankment blocking flow exceeds 25 . The variables used by the HIRE abutment-scour equation are defined the same as those defined for the Froehlich abutmentscour equation. 


\section{Scour Results}

\section{0-yr discharge 500-yr discharge}

Contraction scour:

(Scour depths in feet)

Main channel

Live-bed scour

Clear-water scour

Depth to armoring

Left overbank

Right overbank

Local scour:

Abutment scour

Left abutment

7.5

7.8

8.3

$7.1-$

$10.7-$

$8.7-$

Right abutment

Pier scour

Pier 1

Pier 2

Pier 3

\section{Abutments:}

Left abutment

Right abutment

Piers:

Pier 1

Pier 2

overtopping discharge 


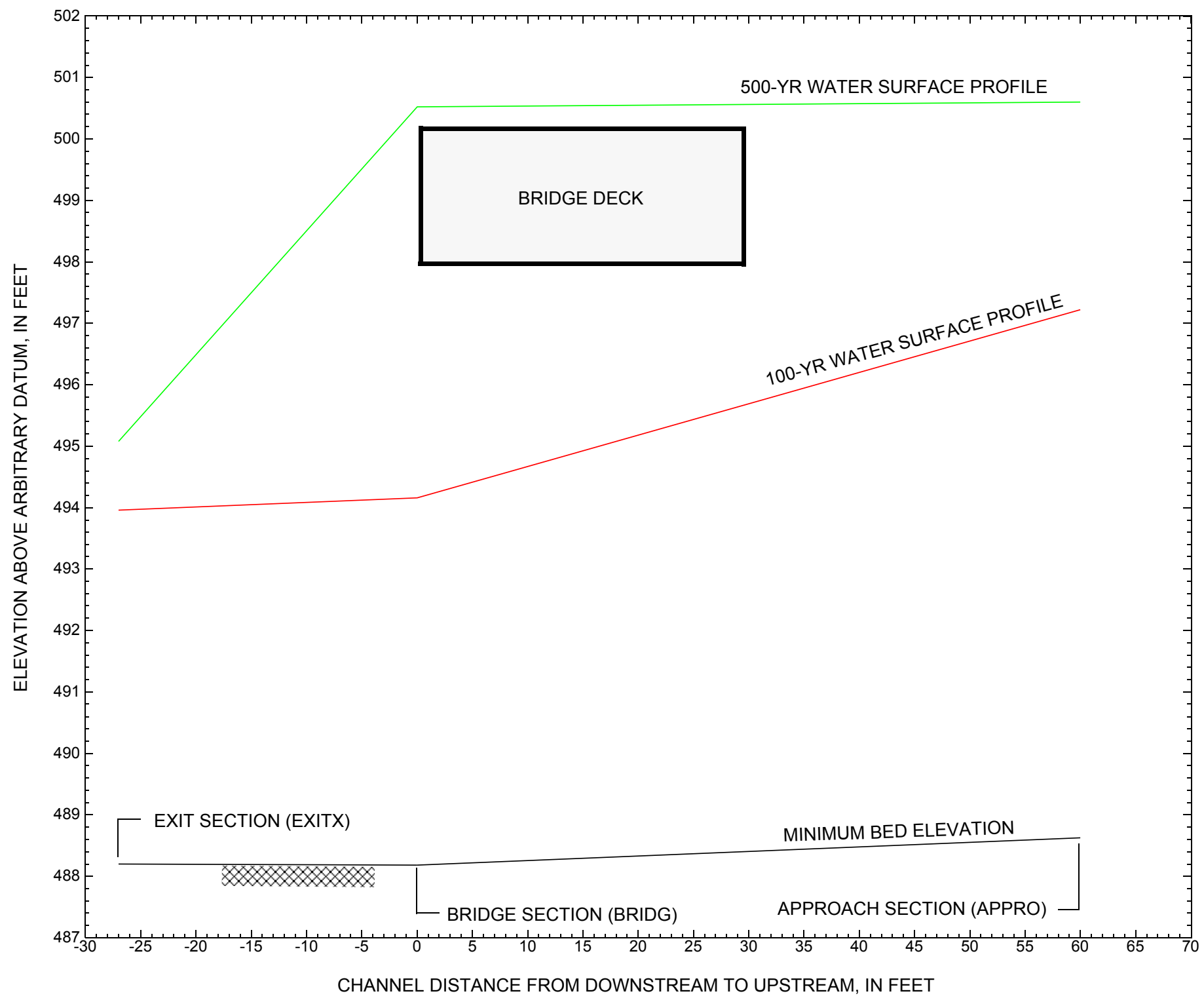

Figure 7. Water-surface profiles for the 100- and 500-yr discharges at structure ANDOTH00010007 on Town Highway 1, crossing Andover Branch, Andover, Vermont. 


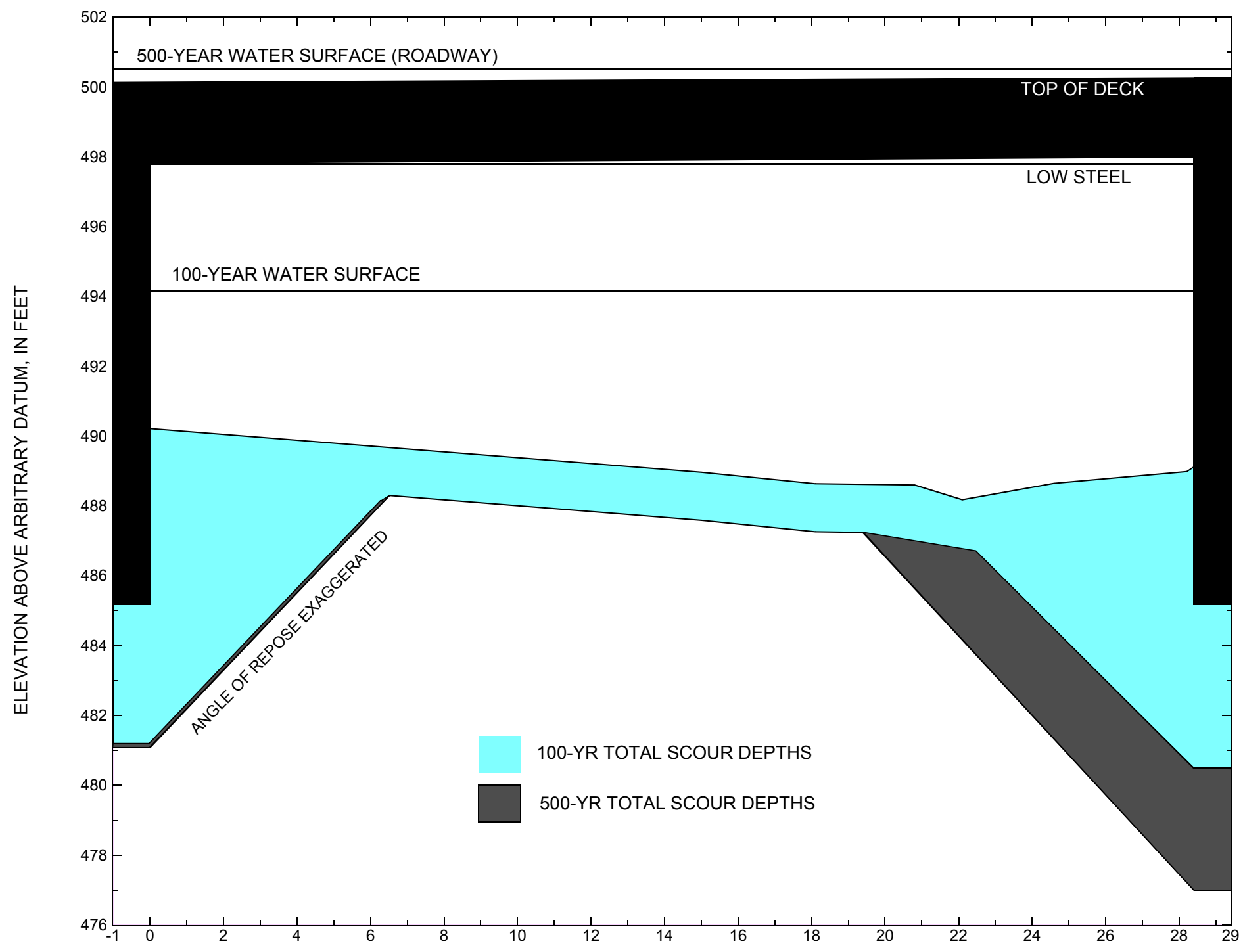

STATIONING FROM LEFT TO RIGHT ALONG BRIDGE SECTION, IN FEET

Figure 8. Scour elevations for the 100-yr and 500-yr discharges at structure ANDOTH00010007 on Town Highway 1, crossing Andover Branch, Andover, Vermont. 
Table 1. Remaining footing/pile depth at abutments for the 100-year discharge at structure ANDOTH00010007 on TOWN HIGHWAY 1, crossing ANDOVER BRANCH, ANDOVER, Vermont.

[VTAOT, Vermont Agency of Transportation; --,no data]

\begin{tabular}{|c|c|c|c|c|c|c|c|c|c|c|c|}
\hline Description & Station $^{1}$ & $\begin{array}{l}\text { VTAOT } \\
\text { minimum } \\
\text { low-chord } \\
\text { elevation } \\
\text { (feet) }\end{array}$ & $\begin{array}{l}\text { Surveyed } \\
\text { minimum } \\
\text { low-chord } \\
\text { elevation }{ }^{2} \\
\text { (feet) }\end{array}$ & $\begin{array}{l}\text { Bottom of } \\
\text { footing } \\
\text { elevation }{ }^{2} \\
\text { (feet) }\end{array}$ & $\begin{array}{c}\text { Channel } \\
\text { elevation at } \\
\text { abutment/ } \\
\text { pier }^{2} \\
\text { (feet) }\end{array}$ & $\begin{array}{l}\text { Contraction } \\
\text { scour depth } \\
\text { (feet) }\end{array}$ & $\begin{array}{l}\text { Abutment } \\
\text { scour } \\
\text { depth } \\
\text { (feet) }\end{array}$ & $\begin{array}{l}\text { Pier } \\
\text { scour } \\
\text { depth } \\
\text { (feet) }\end{array}$ & $\begin{array}{l}\text { Depth of } \\
\text { total scour } \\
\text { (feet) }\end{array}$ & $\begin{array}{c}\text { Elevation of } \\
\text { scour }^{2} \\
\text { (feet) }\end{array}$ & $\begin{array}{c}\text { Remaining } \\
\text { footing/pile } \\
\text { depth } \\
\text { (feet) }\end{array}$ \\
\hline \multicolumn{12}{|c|}{100 -yr. discharge is 1,800 cubic-feet per second } \\
\hline Left abutment & 0.0 & 498.0 & 497.8 & 485.2 & 490.2 & 1.6 & 7.5 & -- & 9.1 & 481.1 & -4.1 \\
\hline Right abutment & 28.4 & 498.2 & 498.0 & 485.2 & 489.0 & 1.6 & 7.1 & -- & 8.7 & 480.3 & -4.9 \\
\hline
\end{tabular}

1.Measured along the face of the most constricting side of the bridge.

2.Arbitrary datum for this study.

Table 2. Remaining footing/pile depth at abutments for the 500-year discharge at structure ANDOTH00010007 on TOWN HIGHWAY 1, crossing ANDOVER BRANCH, ANDOVER, Vermont.

[VTAOT, Vermont Agency of Transportation; --, no data]

\begin{tabular}{|c|c|c|c|c|c|c|c|c|c|c|c|}
\hline Description & Station ${ }^{1}$ & $\begin{array}{l}\text { VTAOT } \\
\text { minimum } \\
\text { low-chord } \\
\text { elevation } \\
\text { (feet) }\end{array}$ & $\begin{array}{l}\text { Surveyed } \\
\text { minimum } \\
\text { low-chord } \\
\text { elevation } \\
\text { (feet) }\end{array}$ & $\begin{array}{c}\text { Bottom of } \\
\text { footing } \\
\text { elevation } \\
\text { (feet) }\end{array}$ & $\begin{array}{l}\text { Channel } \\
\text { elevation at } \\
\text { abutment/ } \\
\text { pier }^{2} \\
\text { (feet) }\end{array}$ & $\begin{array}{l}\text { Contraction } \\
\text { scour depth } \\
\text { (feet) }\end{array}$ & $\begin{array}{l}\text { Abutment } \\
\text { scour } \\
\text { depth } \\
\text { (feet) }\end{array}$ & $\begin{array}{l}\text { Pier } \\
\text { scour } \\
\text { depth } \\
\text { (feet) }\end{array}$ & $\begin{array}{l}\text { Depth of } \\
\text { total scour } \\
\text { (feet) }\end{array}$ & $\begin{array}{c}\text { Elevation of } \\
\text { scour }^{2} \\
\text { (feet) }\end{array}$ & $\begin{array}{c}\text { Remaining } \\
\text { footing/pile } \\
\text { depth } \\
\text { (feet) }\end{array}$ \\
\hline \multicolumn{12}{|c|}{500 -yr. discharge is 2,650 cubic-feet per second } \\
\hline Left abutment & 0.0 & 498.0 & 497.8 & 485.2 & 490.2 & 1.4 & 7.8 & -- & 9.2 & 481.0 & -4.2 \\
\hline Right abutment & 28.4 & 498.2 & 498.0 & 485.2 & 489.0 & 1.4 & 10.7 & -- & 12.1 & 476.9 & -8.3 \\
\hline
\end{tabular}

1.Measured along the face of the most constricting side of the bridge.

2.Arbitrary datum for this study. 


\section{SELECTED REFERENCES}

Arcement, G.J., Jr., and Schneider, V.R., 1989, Guide for selecting Manning's roughness coefficients for natural channels and flood plains: U.S. Geological Survey Water-Supply Paper 2339, 38 p.

Barnes, H.H., Jr., 1967, Roughness characteristics of natural channels: U.S. Geological Survey Water-Supply Paper 1849,213 p.

Benson, M. A., 1962, Factors Influencing the Occurrence of Floods in a Humid Region of Diverse Terrain: U.S. Geological Survey WaterSupply Paper 1580-B, 64 p.

Brown, S.A. and Clyde, E.S., 1989, Design of riprap revetment: Federal Highway Administration Hydraulic Engineering Circular No. 11, Publication FHWA-IP-89-016, 156 p.

Federal Highway Administration, 1983, Runoff estimates for small watersheds and development of sound design: Federal Highway Administration Report FHWA-RD-77-158

Froehlich, D.C., 1989, Local scour at bridge abutments in Ports, M.A., ed., Hydraulic Engineering--Proceedings of the 1989 National Conference on Hydraulic Engineering: New York, American Society of Civil Engineers, p. 13-18.

Hayes, D.C.,1993, Site selection and collection of bridge-scour data in Delaware, Maryland, and Virginia: U.S. Geological Survey WaterResources Investigation Report 93-4017, 23 p.

Interagency Advisory Committee on Water Data, 1982, Guidelines for determining flood flow frequency: U.S. Geological Survey, Bulletin 17B of the Hydrology Subcommittee, 190 p.

Johnson, C.G. and Tasker, G.D.,1974, Progress report on flood magnitude and frequency of Vermont streams: U.S. Geological Survey OpenFile Report 74-130, 37 p.

Lagasse, P.F., Schall, J.D., Johnson, F., Richardson, E.V., Chang, F., 1995, Stream Stability at Highway Structures: Federal Highway Administration Hydraulic Engineering Circular No. 20, Publication FHWA-IP-90-014, 144 p.

Laursen, E.M., 1960, Scour at bridge crossings: Journal of the Hydraulics Division, American Society of Civil Engineers, v. 86, no. HY2, p. 39-53.

Potter, W. D., 1957a, Peak rates of runoff in the Adirondack, White Mountains, and Maine woods area, Bureau of Public Roads

Potter, W. D., 1957b, Peak rates of runoff in the New England Hill and Lowland area, Bureau of Public Roads

Richardson, E.V. and Davis, S.R., 1995, Evaluating scour at bridges: Federal Highway Administration Hydraulic Engineering Circular No. 18, Publication FHWA-IP-90-017, 204 p.

Richardson, E.V., Simons, D.B., and Julien, P.Y., 1990, Highways in the river environment: Federal Highway Administration Publication FHWA-HI-90-016.

Ritter, D.F., 1984, Process Geomorphology: W.C. Brown Co., Debuque, Iowa, 603 p.

Shearman, J.O., 1990, User's manual for WSPRO--a computer model for water surface profile computations: Federal Highway Administration Publication FHWA-IP-89-027, 187 p.

Shearman, J.O., Kirby, W.H., Schneider, V.R., and Flippo, H.N., 1986, Bridge waterways analysis model; research report: Federal Highway Administration Publication FHWA-RD-86-108, 112 p.

Talbot, A.N., 1887, The determination of water-way for bridges and culverts.

U.S. Department of Transportation, 1993, Stream stability and scour at highway bridges, Participant Workbook: Federal Highway Administration Publication FHWA HI-91-011.

U.S. Geological Survey, 1971, Andover, Vermont 7.5 Minute Series quadrangle map: U.S. Geological Survey Topographic Maps, Scale $1: 24,000$. 


\section{APPENDIX A: \\ WSPRO INPUT FILE}




\section{WSPRO INPUT FILE}

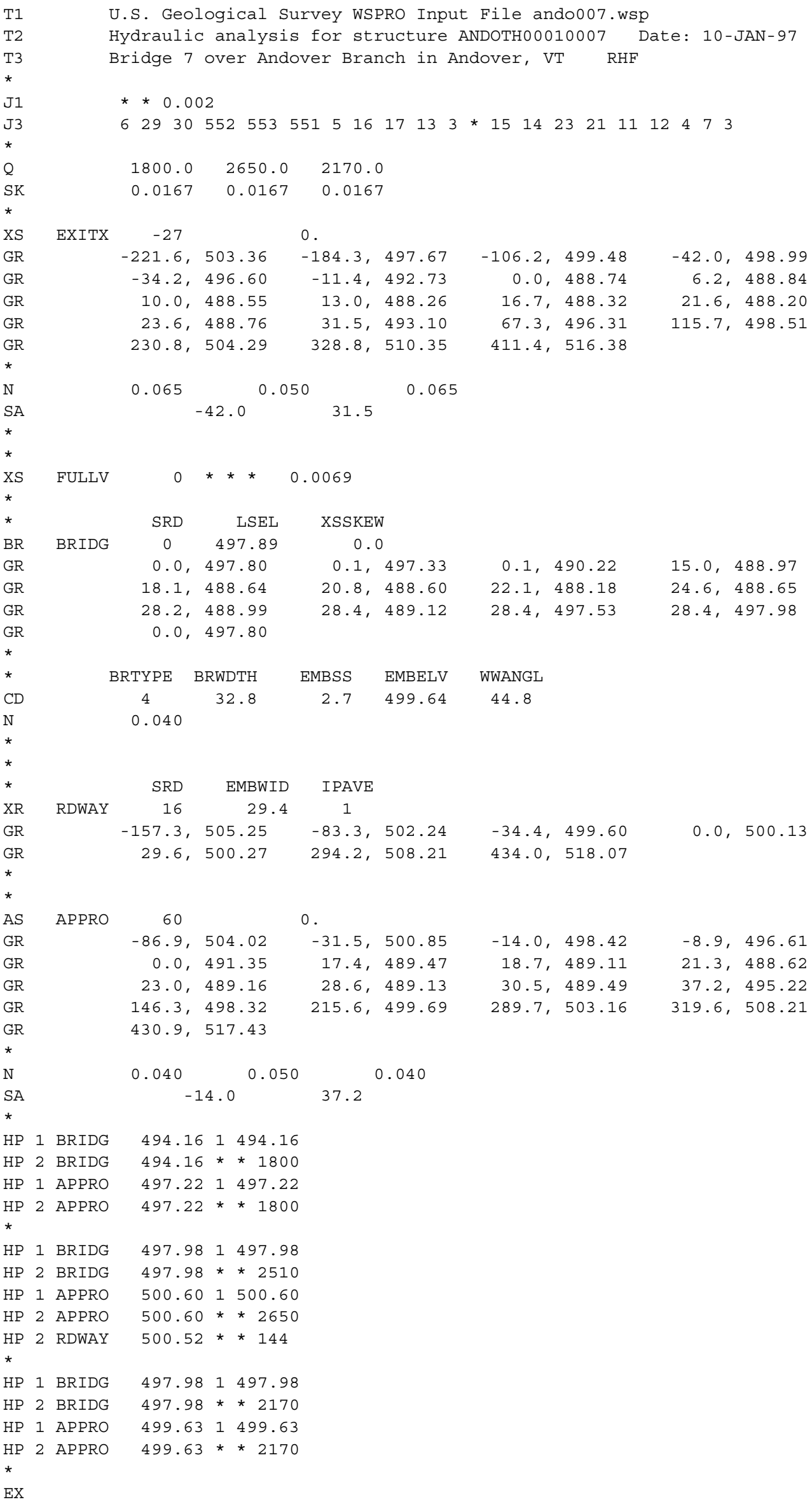




\section{APPENDIX B: \\ WSPRO OUTPUT FILE}




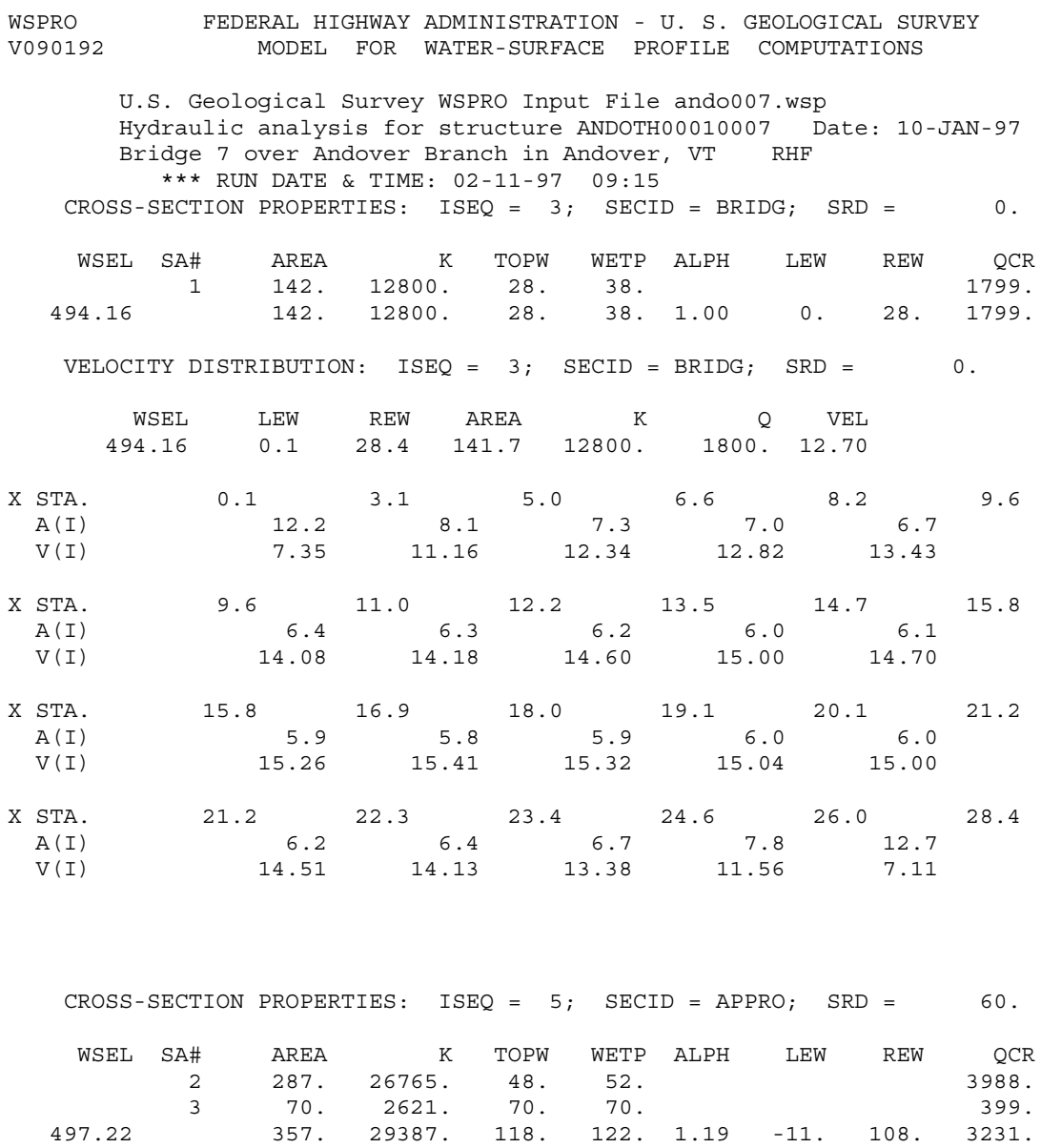

\footnotetext{
VELOCITY DISTRIBUTION : ISEQ $=5 ;$ SECID $=$ APPRO; $\quad$ SRD $=60$.
}

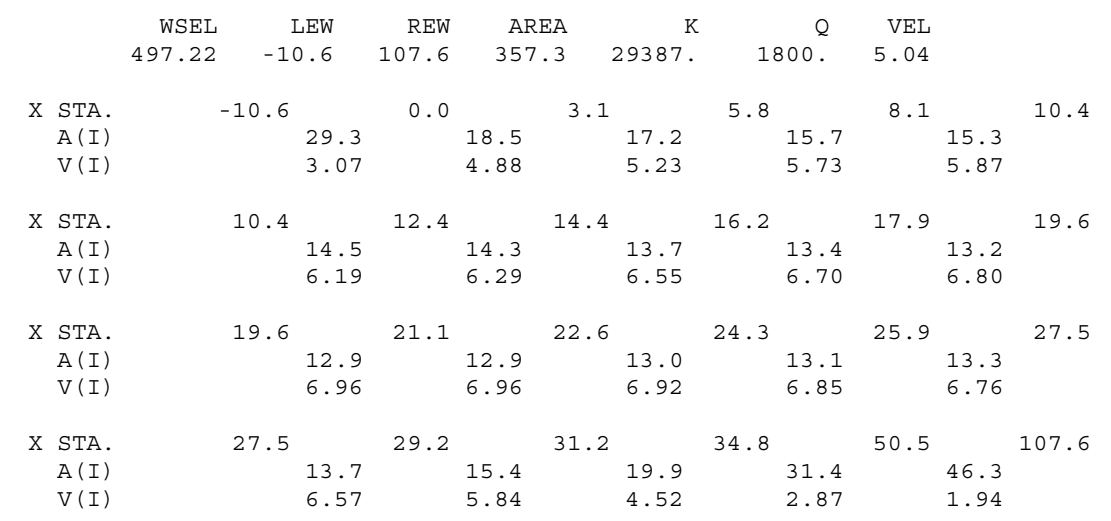




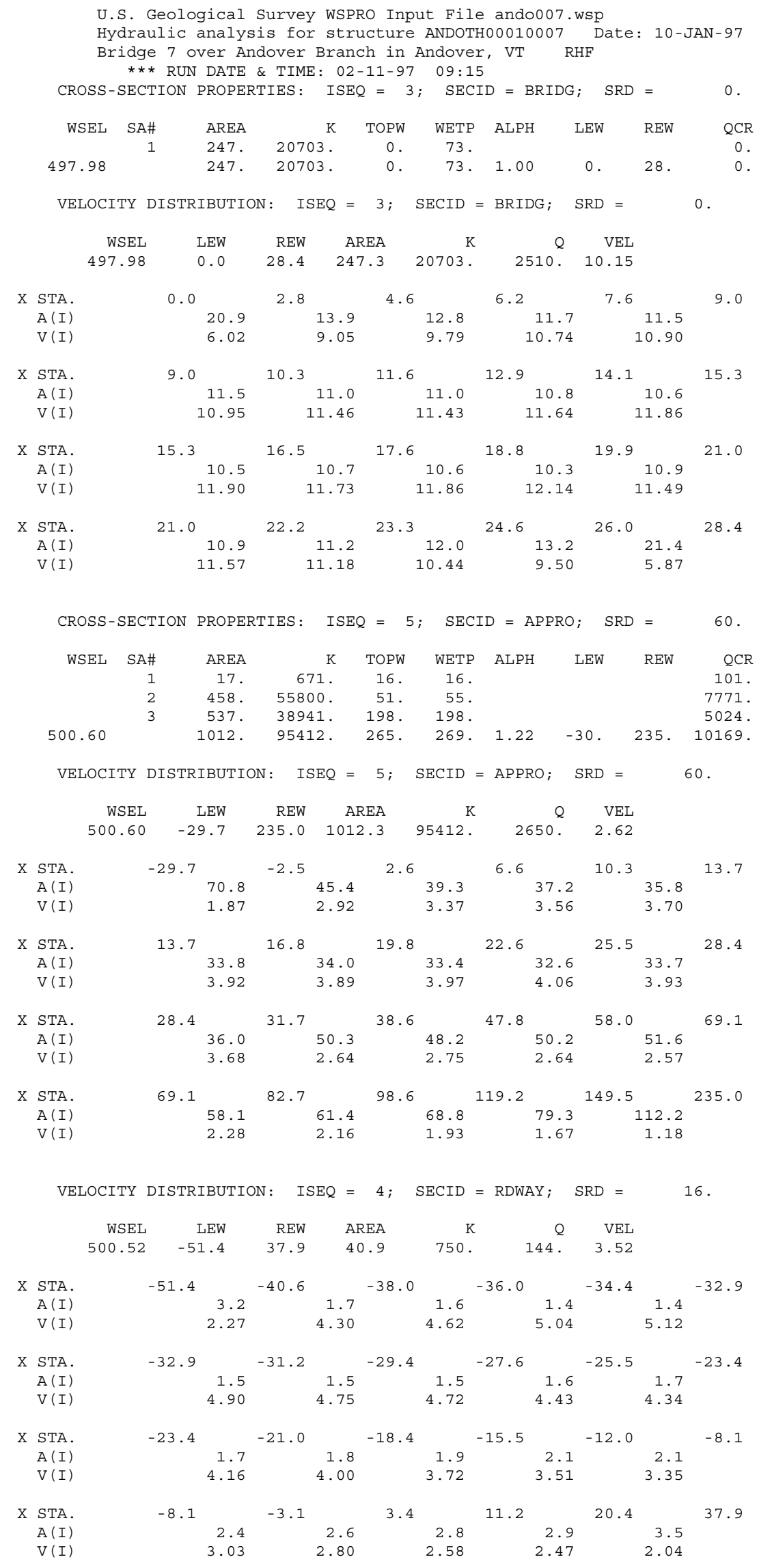


WSPRO OUTPUT FILE (continued)

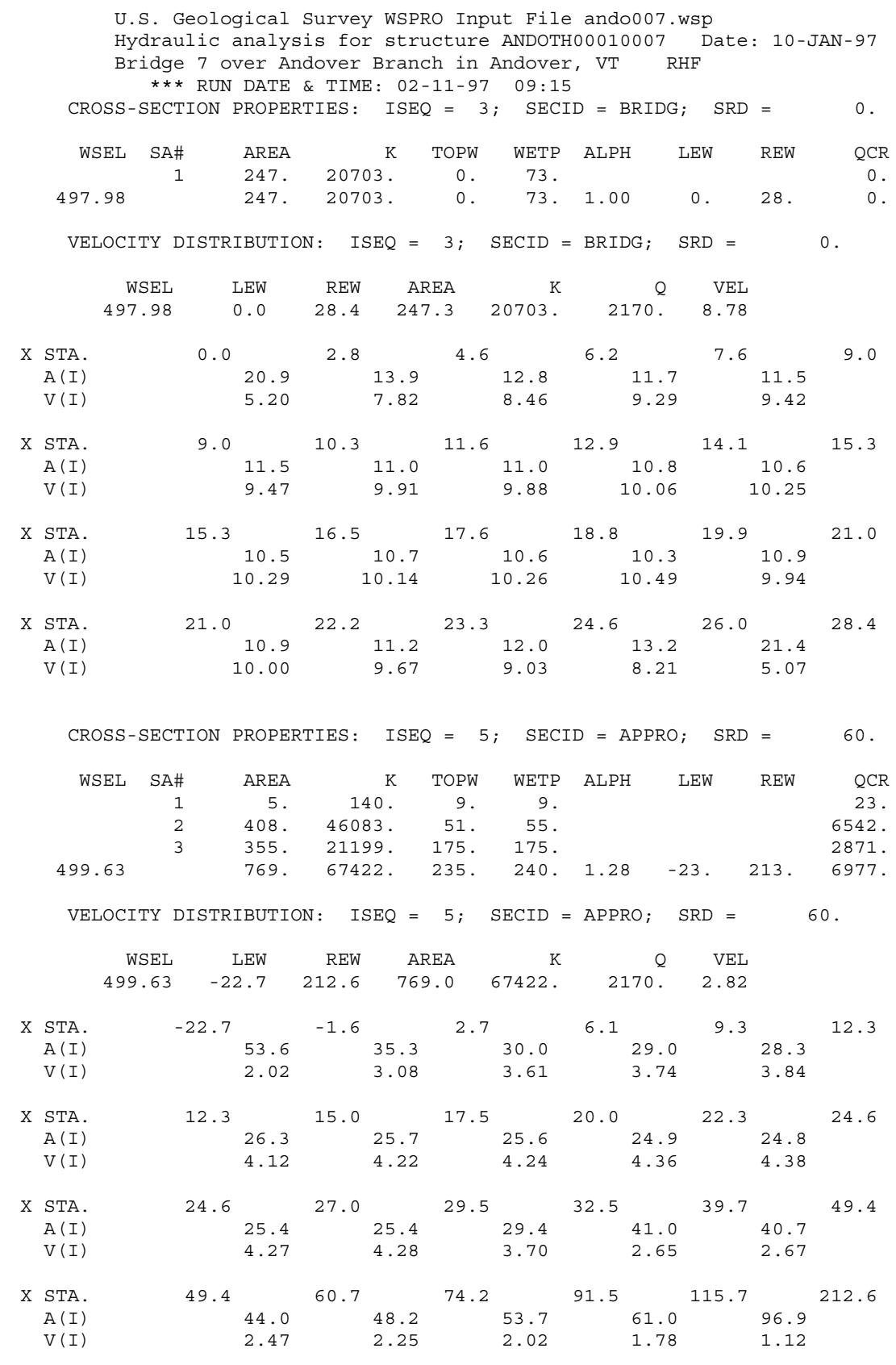


WSPRO OUTPUT FILE (continued)

WSPRO FEDERAL HIGHWAY ADMINISTRATION - U. S. GEOLOGICAL SURVEY

V090192 MODEL FOR WATER-SURFACE PROFILE COMPUTATIONS

U.S. Geological Survey WSPRO Input File ando007.wsp

Hydraulic analysis for structure ANDOTH00010007 Date: 10-JAN-97

Bridge 7 over Andover Branch in Andover, VT RHF

*** RUN DATE \& TIME: 02-11-97 09:15

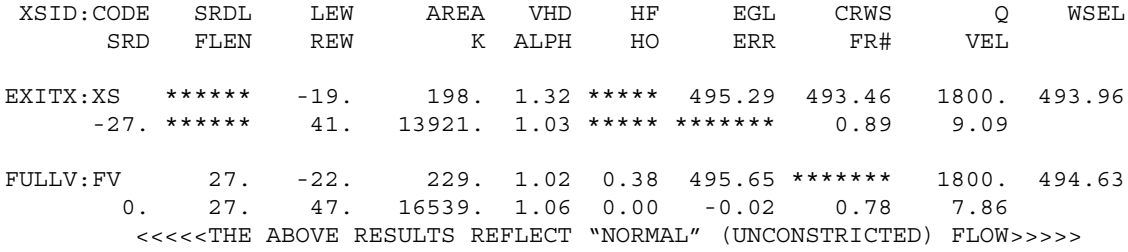

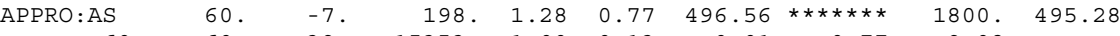

$\begin{array}{llllllll}\text { 60. } 60 . & 39 . & 15353 . & 1.00 & 0.13 & 0.01 & 0.77 & 9.08\end{array}$

$<<<<$ THE ABOVE RESULTS REFLECT "NORMAL" (UNCONSTRICTED) FLOW >>>>>

$==285$ CRITICAL WATER-SURFACE ELEVATION A $-\mathrm{S}_{-} \mathrm{S}_{-} \mathrm{U}_{-} \mathrm{M}_{-} \mathrm{E}-\mathrm{D}$ !!!!!

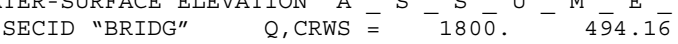

$\ll<<$ RESULTS REFLECTING THE CONSTRICTED FLOW FOLLOW $>>>>>$

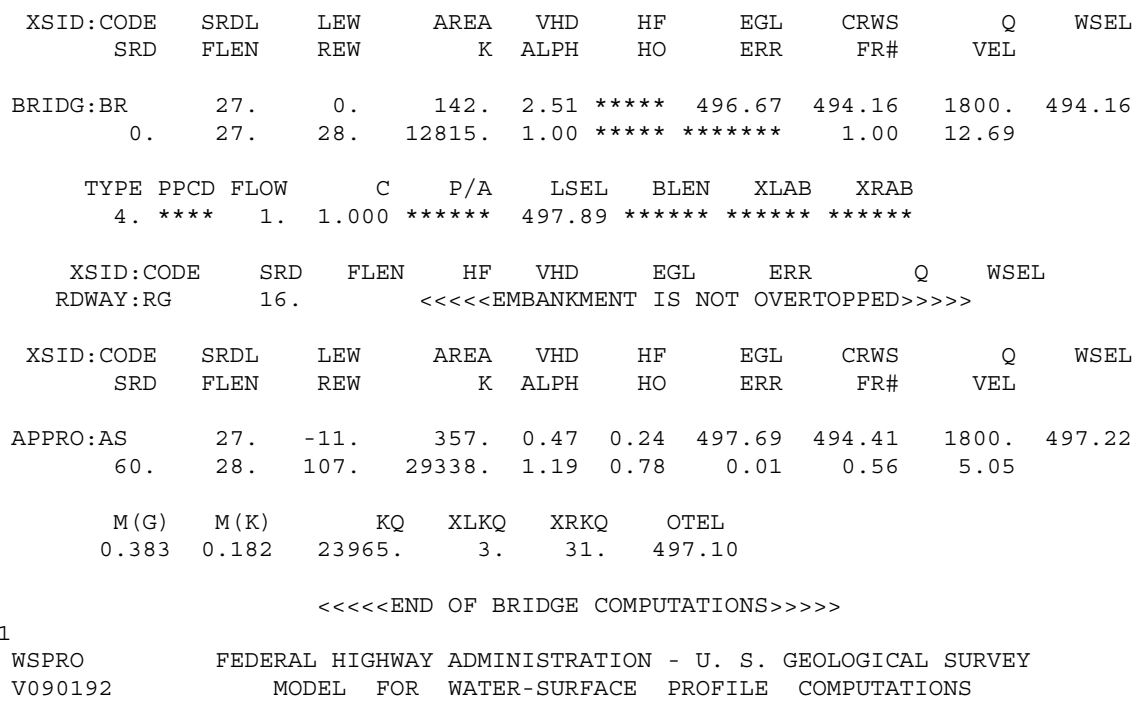

\begin{tabular}{|c|c|c|c|c|c|c|c|c|}
\hline XSID : CODE & SRD & LEW & REW & $\mathrm{Q}$ & $\mathrm{K}$ & AREA & VEL & WSEL \\
\hline EXITX:XS & -27 & -19. & 41. & 1800. & 13921. & 198. & 9.09 & 493.96 \\
\hline FULLV : FV & 0 & -22 & 47. & 1800. & 16539. & 229. & 7.86 & 494.63 \\
\hline BRIDG : BR & 0 . & 0 & 28 & 1800 . & 12815 . & 142. & 12.69 & 494.16 \\
\hline RDWAY : RG & \multicolumn{3}{|c|}{$16 . * * * * * * * * * * * * * *$} & \multicolumn{3}{|c|}{$0 . * * * * * * * * * * * * * * * * * * *$} & \multicolumn{2}{|c|}{$1.00 * * * * * * * *$} \\
\hline APPRO : AS & 60. & -11 & 107. & 1800 . & 29338 & 357. & 5.05 & 497.22 \\
\hline XSID : CODE & XLKQ & $\mathrm{XRKQ}$ & & & & & & \\
\hline APPRO : AS & 3. & 31. & 23965 & & & & & \\
\hline
\end{tabular}

SECOND USER DEFINED TABLE.

$\begin{array}{lcrrrrrrrr}\text { XSID : CODE } & \text { CRWS } & \text { FR\# } & \text { YMIN } & \text { YMAX } & \text { HF } & \text { HO } & \text { VHD } & \text { EGL } & \text { WSEL } \\ \text { EXITX:XS } & 493.46 & 0.89 & 488.20 & 516.38 * * * * * * * * * * & 1.32 & 495.29 & 493.96 \\ \text { FULLV:FV } & * * * * * * * * & 0.78 & 488.39 & 516.57 & 0.38 & 0.00 & 1.02 & 495.65 & 494.63 \\ \text { BRIDG: BR } & 494.16 & 1.00 & 488.18 & 497.98 * * * * * * * * * * & 2.51 & 496.67 & 494.16 \\ \text { RDWAY:RG } & * * * * * * * * * * * * * * * & 499.60 & 518.07 * * * * * * * * * * * * * * * * * * * * * * * * * * * * * * \\ \text { APPRO:AS } & 494.41 & 0.56 & 488.62 & 517.43 & 0.24 & 0.78 & 0.47 & 497.69 & 497.22\end{array}$


WSPRO OUTPUT FILE (continued)

WSPRO

V090192
FEDERAL HIGHWAY ADMINISTRATION - U. S. GEOLOGICAL SURVEY MODEL FOR WATER-SURFACE PROFILE COMPUTATIONS

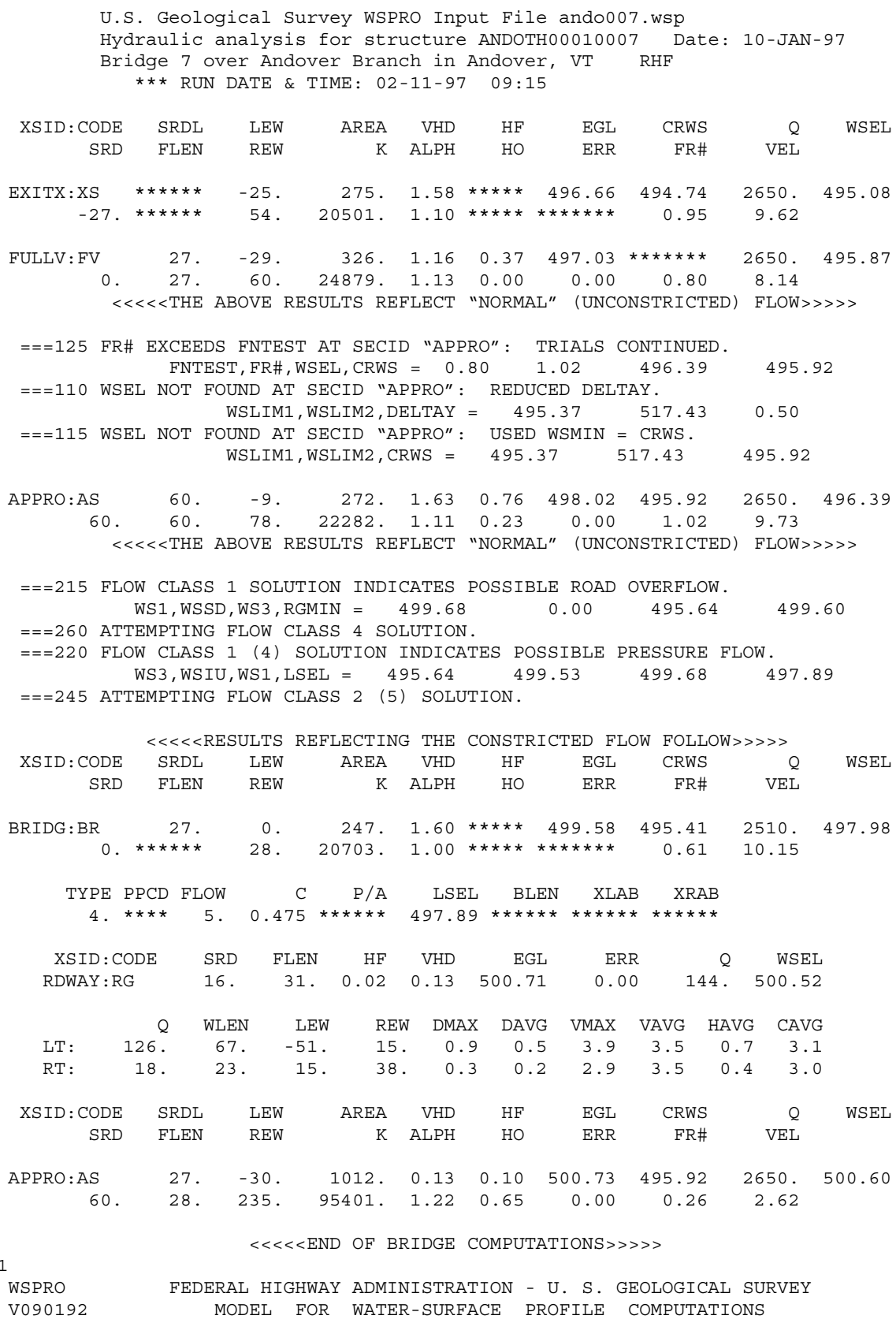

$\begin{array}{lcrrrrrrrr}\text { XSID:CODE } & \text { CRWS } & \text { FR\# } & \text { YMIN } & \text { YMAX } & \text { HF } & \text { HO } & \text { VHD } & \text { EGL } & \text { WSEL } \\ \text { EXITX:XS } & 494.74 & 0.95 & 488.20 & 516.38 * * * * * * * * * * * & 1.58 & 496.66 & 495.08 \\ \text { FULLV:FV } & * * * * * * * & 0.80 & 488.39 & 516.57 & 0.37 & 0.00 & 1.16 & 497.03 & 495.87 \\ \text { BRIDG:BR } & 495.41 & 0.61 & 488.18 & 497.98 * * * * * * * * * * * & 1.60 & 499.58 & 497.98 \\ \text { RDWAY: RG } & * * * * * * * * * * * * * * & 499.60 & 518.07 & 0.02 * * * * * & 0.13 & 500.71 & 500.52 \\ \text { APPRO:AS } & 495.92 & 0.26 & 488.62 & 517.43 & 0.10 & 0.65 & 0.13 & 500.73 & 500.60\end{array}$


WSPRO OUTPUT FILE (continued)

WSPRO FEDERAL HIGHWAY ADMINISTRATION - U. S. GEOLOGICAL SURVEY

V090192 MODEL FOR WATER-SURFACE PROFILE COMPUTATIONS

U.S. Geological Survey WSPRO Input File ando007.wsp

Hydraulic analysis for structure ANDOTH00010007 Date: 10-JAN-97

Bridge 7 over Andover Branch in Andover, VT RHF

*** RUN DATE \& TIME: 02-11-97 09:15

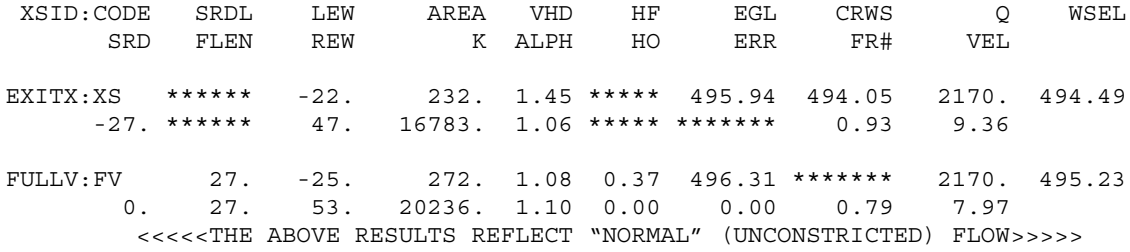

$==125$ FR\# EXCEEDS FNTEST AT SECID "APPRO": TRIALS CONTINUED.

FNTEST, FR\#, WSEL, CRWS $=0.80 \quad 0.92 \quad 495.80 \quad 494.96$

$==110$ WSEL NOT FOUND AT SECID "APPRO": REDUCED DELTAY.

WSLIM1,WSLIM2, DELTAY $=494.73 \quad 517.43 \quad 0.50$

$==115$ WSEL NOT FOUND AT SECID "APPRO": USED WSMIN = CRWS

WSLIM1, WSLIM2, CRWS $=494.73 \quad 517.43 \quad 494.96$

$\begin{array}{llllllllll}\text { APPRO }: A S & 60 . & -8 . & 227 . & 1.47 & 0.76 & 497.27 & 494.96 & 2170 . & 495.79\end{array}$

60. 60. 57. 18257. 1.04 $0.20 \quad 0.00 \quad 0.92 \quad 9.56$

$<<<<$ THE ABOVE RESULTS REFLECT "NORMAL" (UNCONSTRICTED) FLOW >>>>

$==220$ FLOW CLASS 1 (4) SOLUTION INDICATES POSSIBLE PRESSURE FLOW.

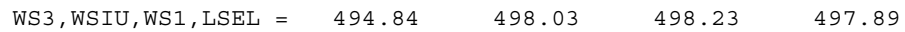

$==245$ ATTEMPTING FLOW CLASS 2 (5) SOLUTION.

$<<<<$ RESULTS REFLECTING THE CONSTRICTED FLOW FOLLOW $>>>>>$

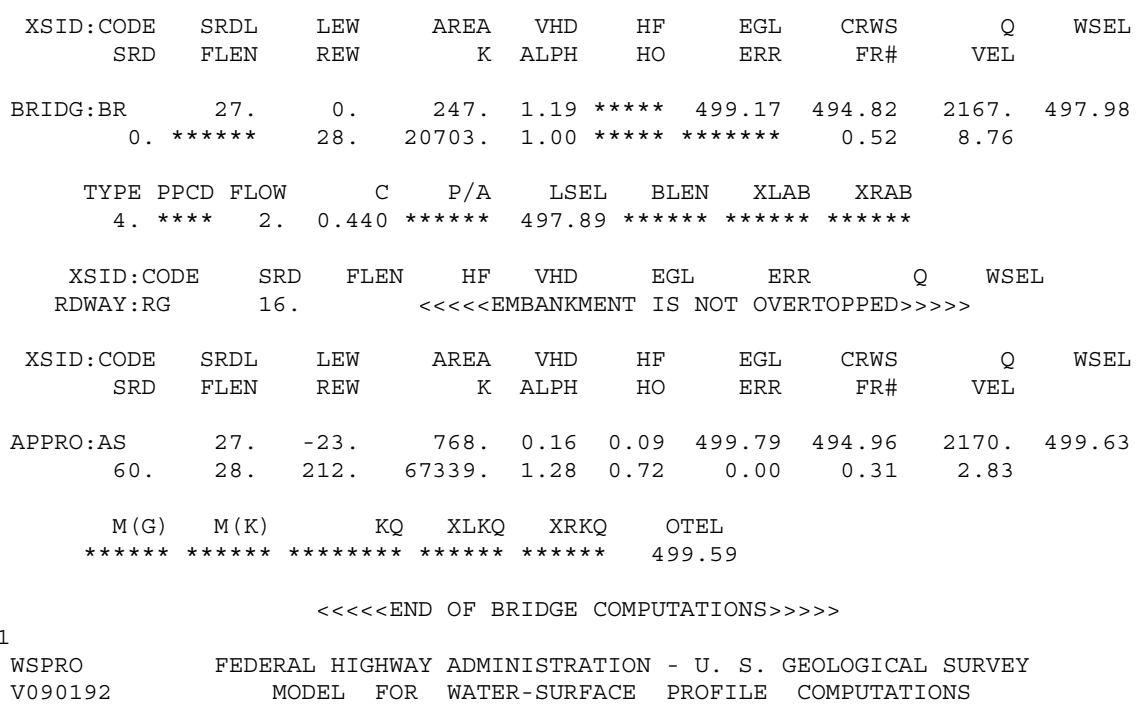

\begin{tabular}{|c|c|c|c|c|c|c|c|c|}
\hline XSID: CODE & SRD & LEW & REW & $Q$ & $\mathrm{~K}$ & AREA & VEL & WSEL \\
\hline EXITX:XS & -27 & -22 & 47. & 2170 . & 16783. & 232 . & 9.36 & 494.49 \\
\hline FULLV : FV & 0 . & -25 & 53. & 2170 . & 20236 . & 272 . & 7.97 & 495.23 \\
\hline BRIDG : BR & 0 & 0 & 28. & 2167. & 20703. & 247 & 8.76 & 497.98 \\
\hline RDWAY : RG & \multicolumn{3}{|l|}{$16 . * *$} & 0 . & 0 & 0 . & \multicolumn{2}{|c|}{ 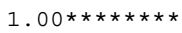 } \\
\hline APPRO : AS & 60 & -23 & 212 . & 2170 . & 67339. & 768. & 2.83 & 499.63 \\
\hline
\end{tabular}

SECOND USER DEFINED TABLE.

\begin{tabular}{|c|c|c|c|c|c|c|c|c|c|}
\hline XSID : CODE & CRWS & FR\# & YMIN & YMAX & $\mathrm{HF}$ & $\mathrm{HO}$ & VHD & EGL & WSEL \\
\hline EXITX:XS & 494.05 & 0.93 & 488.20 & 516.38 * & $\star * \star * \star * *$ & $\star \star \star \star \star *$ & 1.45 & 495.94 & 494.49 \\
\hline FULLV : FV & $\star \star \star \star \star \star * \star * *$ & 0.79 & 488.39 & 516.57 & 0.37 & 0.00 & 1.08 & 496.31 & 495.2 \\
\hline BRIDG : BR & 494.82 & 0.52 & 488.18 & 497.98 * & $* * * * * *$ & 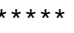 & 1.19 & 499.17 & 497.9 \\
\hline RDWAY : RG & 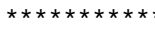 & $* \star \star \star *$ & 499.60 & $518.07 *$ & $* * * * * *$ & 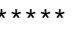 & 0.16 & $499.75 *$ & \\
\hline APPRO : AS & 494.96 & 0.31 & 488.62 & 517.43 & 0.09 & 0.72 & 0.16 & 499.79 & 499.6 \\
\hline
\end{tabular}

1 NORMAL END OF WSPRO EXECUTION. 


\section{APPENDIX C:}

\section{BED-MATERIAL PARTICAL-SIZE DISTRIBUTION}




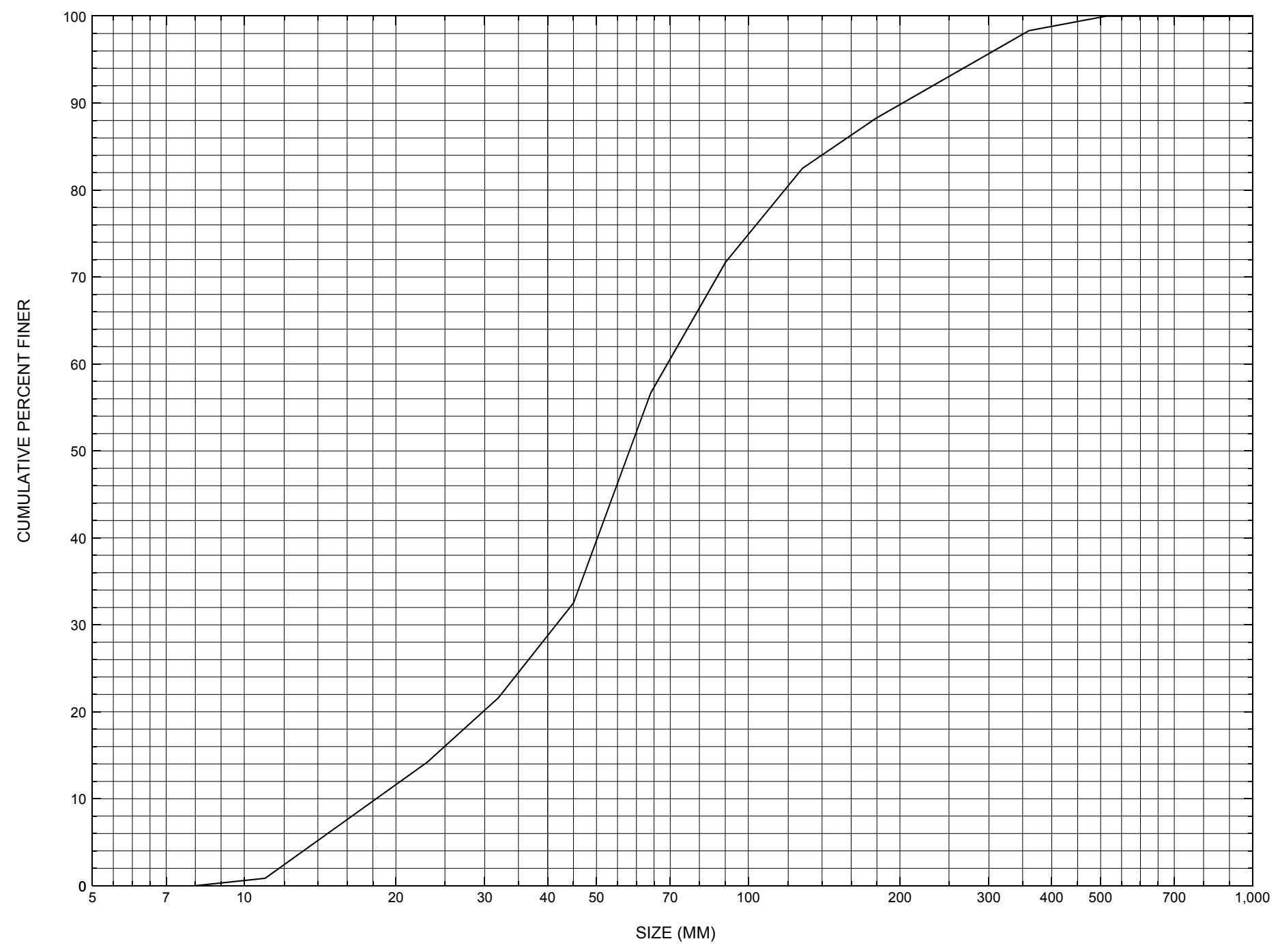

Appendix C. Bed material particle-size distribution for a pebble count in the channel approach of structure ANDOTH00010007, in Andover, Vermont. 


\section{APPENDIX D: \\ HISTORICAL DATA FORM}




\section{Structure Number ANDOTH00010007}

\section{General Location Descriptive}

Data collected by (First Initial, Full last name) $\mathbf{M}$. IVANOFF

Date $(M M / D D / Y Y) \_\mathbf{0 3} / \underline{\mathbf{2 8}} / \underline{\mathbf{9 5}}$

Highway District Number (I - 2; nn) $\mathbf{0 2}$

Town (FIPS place code; I - 4; nnnnn) $\mathbf{0 1 3 0 0}$

Waterway (I - 6) ANDOVER BRANCH

Route Number TH01

Topographic Map Andover

Latitude (I - 16; nnnn.n) $\mathbf{4 3 1 6 4}$
County (FIPS county code; I - 3; nnn)

Mile marker (I - 11; nnn.nnn) $\mathbf{0 0 4 5 2 0}$

Road Name (I - 7): -

Vicinity (I - 9) 1.9 MI N JCT. VT.11

Hydrologic Unit Code: $\mathbf{0 1 0 8 0 1 0 7}$

Longitude (i - 17; nnnnn.n) $\mathbf{7 2 4 1 5}$

\section{Select Federal Inventory Codes}

FHWA Structure Number (I - 8) 20013200071401

Maintenance responsibility $(I-21 ; n n) \quad \mathbf{0 3} \quad$ Maximum span length $(I-48 ; n n n n) \underline{\mathbf{0 0 2 9}}$

Year built (I - 27; YYYY) 1979

Structure length (I - 49; nnnnnn) $\underline{\mathbf{0 0 0 0 3 2}}$

Average daily traffic, ADT (I - 29; nnnnnn) $\underline{000770}$

Deck Width (I - 52; nn.n) 294

Year of ADT (I - 30; YY) $\mathbf{9 1}$

Channel \& Protection $(I-61 ; n)$

Opening skew to Roadway $(I-34 ; n n) \quad \mathbf{0 0}$

Waterway adequacy $(I-71 ; n) \underline{8}$

Operational status $(I-41 ; X) \quad \mathbf{A}$

Underwater Inspection Frequency $(I-92 B ; X Y Y) \_\mathbf{N}$

Structure type (I - 43; nnn) 101

Year Reconstructed (I - 106) $\mathbf{0 0 0 0}$

Approach span structure type (I - 44; nnn) $\mathbf{0 0 0}$ Clear span (nnn.n ft) _ _

Number of spans (I - 45; nnn) $\underline{\mathbf{0 0 1}}$

Vertical clearance from streambed (nnn.n ft) $\underline{\mathbf{8 . 5}}$

Number of approach spans (I - 46; nnnn) $\mathbf{0 0 0 0}$

Waterway of full opening $\left(n n n . n \mathrm{ft}^{2}\right)$

Comments:

The structural inspection report of 8/3/94 indicates the structure is a concrete slab type bridge with an asphalt road surface. The structure is part of the Federal Aid System and is listed under the route number FAS 132. Both concrete abutment walls are clean with the exception of some hairline vertical cracks. The most severe vertical crack is at the end of the upstream right abutment. The concrete wingwalls are reportedly "like-new". The footings are not in view. A shallow gravel point bar is noted on the left abutment side of the channel with flow along the right abutment. The banks are well protected with stone fill. Some granite block riprap is exposed along the front of the right abutment. The (Continued, page 33) 


\section{Bridge Hydrologic Data}

Is there hydrologic data available? $\underline{\mathbf{Y}}$ if No, type ctrl-n $h \quad$ VTAOT Drainage area $\left(\mathrm{mi}^{2}\right): \underline{\mathbf{7 . 0 6}}$

Terrain character:

Stream character \& type: -

Streambed material:

Discharge Data (cfs):

$$
\mathrm{Q}_{2.33} \frac{-}{\mathbf{1 5 0 0}}
$$

Record flood date (MM / DD / YY):

Estimated Discharge (cfs): 1200 Ice conditions (Heavy, Moderate, Light) : -

$\mathrm{Q}_{10} \frac{\mathbf{9 0 0}}{\mathbf{1 8 0 0}}$

$\mathrm{Q}_{25} \frac{\mathbf{1 2 0 0}}{\mathrm{Q}_{500}-}$

Water surface elevation (ft):

Velocity at $\mathrm{Q} \underline{\mathbf{2 5}}$ $(f t / s): \quad 11.8$

The stage increases to maximum highwater elevation (Rapidly, Not rapidly): _-

The stream response is (Flashy, Not flashy):

Describe any significant site conditions upstream or downstream that may influence the stream's stage: -

Watershed storage area (in percent): _ _ \%

The watershed storage area is: (1-mainly at the headwaters; 2- uniformly distributed; 3-immediatly upstream oi the site)

Water Surface Elevation Estimates for Existing Structure:

\begin{tabular}{|l|l|l|l|l|l|}
\hline Peak discharge frequency & $Q_{2.33}$ & $Q_{10}$ & $Q_{25}$ & $Q_{50}$ & $Q_{100}$ \\
Water surface elevation (ft)) & - & $\mathbf{4 . 8}$ & $\mathbf{5 . 8}$ & $\mathbf{6 . 7}$ & $\mathbf{7 . 6}$ \\
Velocity $(\mathrm{ft} / \mathrm{sec})$ & - & - & - & - & - \\
\hline
\end{tabular}

Long term stream bed changes: -

Is the roadway overtopped below the $\mathrm{Q}_{100}$ ? (Yes, No, Unknown): $\mathbf{U}$ Frequency: Relief Elevation (ft): Discharge over roadway at $Q_{100}\left(f^{3} / \mathrm{sec}\right)$ :

Are there other structures nearby? (Yes, No, Unknown): $\underline{\mathbf{U}}$ Upstream distance (miles): Town: If No or Unknown, type ctrl-n os Highway No. : Structure No. : Year Built:

Clear span (ft): Clear Height (ft): Full Waterway $\left(f^{2}\right)$ : 
Downstream distance (miles): Town: Year Built:

Highway No. : Structure No. : Structure Type:

Clear span (ft): Clear Height $(f t)$ : Full Waterway $\left(f^{2}\right)$ :

Comments:

channel makes a slight turn into bridge. There is stone fill reported on the bed under the bridge.

\section{USGS Watershed Data}

Watershed Hydrographic Data

Drainage area $(D A)$ $\mathrm{mi}^{2}$ Lake and pond area

0.01 $\mathrm{mi}^{2}$

Watershed storage (ST) 0.1

Bridge site elevation 1060 $\mathrm{ft}$ $\%$

Main channel length 4.89 mi

$10 \%$ channel length elevation 1120 $\mathrm{ft} \quad 85 \%$ channel length elevation 2020 $\mathrm{ft}$

Main channel slope $(S)$

(S) 245.45 $\mathrm{ft} / \mathrm{mi}$

Watershed Precipitation Data

Average site precipitation in Average headwater precipitation in

Maximum 2yr-24hr precipitation event $(124,2)$ in

Average seasonal snowfall (Sn) $\mathrm{ft}$ 


\section{Bridge Plan Data}

Are plans available? $\mathbf{Y}$ If no, type ctrl-n pl Date issued for construction (MM/YYYY): 06 / 1979 Project Number BRS 0132(4)S Minimum channel bed elevation: 4 487.0

Low superstructure elevation: USLAB $\underline{497.14}$ DSLAB $\underline{497.14}$ USRAB $\underline{\text { 497.32 }}$ DSRAB $\underline{\text { 497.32 }}$ Benchmark location description:

Spike in root or trunk of an 18 inch white birch tree, $B M \# 2$, elevation 499.45 , located about 40 feet leftbankward from the left abutment and about 20 feet perpendicular from roadway center line in the downstream direction just behind the seventh guard rail post from the left bank end.

Reference Point (MSL, Arbitrary, Other): Arbitrary $\quad$ Datum (NAD27, NAD83, Other): Arbitrary Foundation Type: 1 (1-Spreadfooting; 2-Pile; 3- Gravity; 4-Unknown)

If 1: Footing Thickness $\mathbf{2 . 0} \quad$ Footing bottom elevation: $\underline{\mathbf{4 8 5 . 0}}$

If 2: Pile Type:___ (1-Wood; 2-Steel or metal; 3-Concrete) Approximate pile driven length:

If 3: Footing bottom elevation:

Is boring information available? $\mathbf{N}$ If no, type ctrl- $n$ bi Number of borings taken: _-

Foundation Material Type: $\mathbf{3}$ (1-regolith, 2-bedrock, 3-unknown)

Briefly describe material at foundation bottom elevation or around piles:

NO FOUNDATION MATERIAL INFORMATION.

\section{Comments:}

Plans stamped built as designed. Bridge will handle a Q100 without overtopping. Other elevation points:

1. the point on the top streamward edge of the upstream left wingwall where the concrete slope changes to a decline, elevation 499.49; 2 . the point at the same location described above except on the upstream right wingwall, elevation 499.67 . 


\section{Cross-sectional Data}

Is cross-sectional data available? $\underline{\mathbf{Y}}$ If no, type ctrl-n xs

Source (FEMA, VTAOT, Other)? VTAOT

Comments: Upstream brige face cross section from left to right bank. At this section the channel was graded to an elevation of 489.0. The channel baseline runs along the left bank perpindicular to and 1 foot from the left abutment streamward face.

\begin{tabular}{|l|l|l|l|l|l|l|l|l|l|l|l|}
\hline Station & $\mathbf{1}$ & $\mathbf{1 7}$ & $\mathbf{2 9}$ & - & - & - & - & - & - & - & - \\
\hline Feature & LCL & - & LCR & - & - & - & - & - & - & - & - \\
\hline $\begin{array}{l}\text { Low cord } \\
\text { elevation }\end{array}$ & $\mathbf{4 9 7 . 8}$ & - & $\mathbf{4 9 8 . 0}$ & - & - & - & - & - & - & - & - \\
\hline $\begin{array}{l}\text { Bed } \\
\text { elevation }\end{array}$ & $\mathbf{4 8 9 . 0}$ & $\mathbf{4 8 9 . 0}$ & $\mathbf{4 8 9 . 0}$ & - & - & - & - & - & - & - & - \\
\hline $\begin{array}{l}\text { Low cord to } \\
\text { bed length }\end{array}$ & $\mathbf{8 . 8}$ & - & $\mathbf{9 . 0}$ & - & - & - & - & - & - & - & - \\
\hline Station & - & - & - & - & - & - & - & - & - & - & - \\
\hline Feature & - & - & - & - & - & - & - & - & - & - & - \\
\hline $\begin{array}{l}\text { Low cord } \\
\text { elevation }\end{array}$ & - & - & - & - & - & - & - & - & - & - & - \\
\hline $\begin{array}{l}\text { Bed } \\
\text { elevation }\end{array}$ & - & - & - & - & - & - & - & - & - & - & - \\
\hline $\begin{array}{l}\text { Low cord to } \\
\text { bed length }\end{array}$ & - & - & - & - & - & - & - & - & - & - & - \\
\hline
\end{tabular}

Source (FEMA, VTAOT, Other)? VTAOT

Comments: Downstream bridge face cross section from left to right bank. Also, this section was graded to an elevation of 489.0 .

\begin{tabular}{|l|l|l|l|l|l|l|l|l|l|l|l|}
\hline Station & 2 & 11 & 17 & 29 & 31.5 & - & - & - & - & - & - \\
\hline Feature & LCL & - & - & - & LCR & - & - & - & - & - & - \\
\hline $\begin{array}{l}\text { Low cord } \\
\text { elevation }\end{array}$ & 497.8 & - & - & - & 498.0 & - & - & - & - & - & - \\
\hline $\begin{array}{l}\text { Bed } \\
\text { elevation }\end{array}$ & 489.0 & 489.0 & 489.0 & 489.0 & 489.0 & - & - & - & - & - & - \\
\hline $\begin{array}{l}\text { Low cord to } \\
\text { bed length }\end{array}$ & 8.8 & - & - & - & 9.0 & - & - & - & - & - & - \\
\hline Station & - & - & - & - & - & - & - & - & - & - & - \\
\hline Feature & - & - & - & - & - & - & - & - & - & - & - \\
\hline $\begin{array}{l}\text { Low cord } \\
\text { elevation }\end{array}$ & - & - & - & - & - & - & - & - & - & - & - \\
\hline $\begin{array}{l}\text { Bed } \\
\text { elevation }\end{array}$ & - & - & - & - & - & - & - & - & - & - & - \\
\hline $\begin{array}{l}\text { Low cord to } \\
\text { bed length }\end{array}$ & - & - & - & - & - & - & - & - & - & - & - \\
\hline
\end{tabular}




\section{APPENDIX E: \\ LEVEL I DATA FORM}


U. S. Geological Survey

Bridge Field Data Collection and Processing Form

Qa/Qc Check by: $\underline{\mathbf{R B}}$ Date: $09 / \mathbf{2 4 / 9 6}$

\section{Structure Number}

ANDOTH00010007

Computerized by: $\underline{\mathbf{R B}}$ Date: $09 / 25 / 96$

Reviewd by: $\quad$ RF Date: $\underline{01 / 24 / 97}$

\section{A. General Location Descriptive}

1. Data collected by (First Initial, Full last name) R. HAMMOND

2. Highway District Number $\mathbf{0 2}$

Mile marker $\mathbf{0 0 4 5 2 0}$

County 027 WINDSOR

Town 01300 ANDOVER

Waterway (I - 6) ANDOVER BRANCH

Route Number TH01

Road Name -

Hydrologic Unit Code: $\mathbf{0 1 0 8 0 1 0 7}$

3. Descriptive comments:

Located 1.9 miles north of the junction with VT 11 and about 0.4 miles west of the town line at the junction with the dirt road.

\section{B. Bridge Deck Observations}
4. Surface cover... LBUS 4
RBUS 4
LBDS 6
RBDS 6
Overall 6

(2b us,ds,lb,rb: 1- Urban; 2- Suburban; 3- Row crops; 4- Pasture; 5- Shrub- and brushland; 6- Forest; 7- Wetland)
5. Ambient water surface... US 2
UB 2
DS 2
(1- pool; 2- riffle)

6. Bridge structure type 1 (1- single span; 2- multiple span; 3- single arch; 4- multiple arch; 5-cylindrical culvert; 6- box culvert; or 7- other)
7. Bridge length $\mathbf{3 2}$
(feet)
Span length 29
(feet)
Bridge width 29.4 (feet)

\section{Road approach to bridge:}
8. LB 0
RB 2
( 0 even, 1- lower, 2- higher)
9. LB 1
RB 1
(1- Paved, 2- Not paved)

10. Embankment slope (run / rise in feet / foot)

$$
\text { US left }
$$

3.3:1

US right

2.0:1

\begin{tabular}{|c|c|c|c|c|}
\cline { 2 - 5 } & \multicolumn{2}{|c|}{ Protection } & 13. Erosion & 14.Severity \\
\cline { 2 - 5 } LBUS & 11.Type & 12.Cond. & $\underline{\mathbf{1}}$ & $\frac{\mathbf{1}}{\mathbf{1}}$ \\
\cline { 2 - 5 } RBUS & $\mathbf{1}$ & $\underline{\mathbf{1}}$ & $\underline{\mathbf{2}}$ \\
RBDS & $\mathbf{1}$ & $\underline{\mathbf{1}}$ & $\underline{\mathbf{1}}$ \\
LBDS & $\mathbf{1}$ & $\underline{\mathbf{1}}$ & $\underline{\mathbf{1}}$ \\
\hline
\end{tabular}

Bank protection types: 0 - none; 1- $<12$ inches;

2- < 36 inches; 3- < 48 inches;

4- < 60 inches; 5- wall / artificial levee

Bank protection conditions: 1- good; 2- slumped;

3- eroded; 4- failed

Erosion: 0 - none; 1- channel erosion; 2-

road wash; 3- both; 4- other

Erosion Severity: 0 - none; 1- slight; 2- moderate; 3- severe

\section{Channel approach to bridge (BF):}

15. Angle of approach: $\mathbf{1 0}$

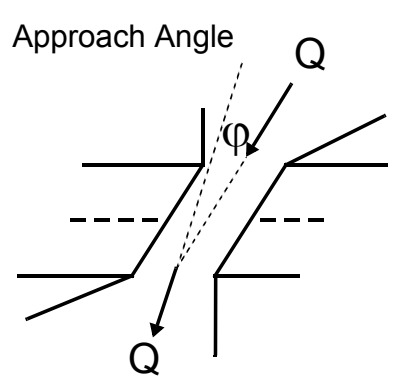

17. Channel impact zone 1 :

Where? RB (LB, RB)

Range? 35 feet US

Channel impact zone 2:

Where? RB (LB, RB)

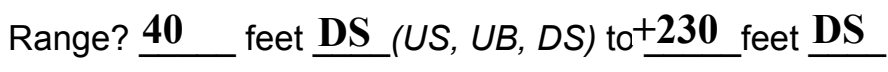

Impact Severity: 0- none to very slight; 1- Slight; 2- Moderate; 3- Severe
16. Bridge skew: 10

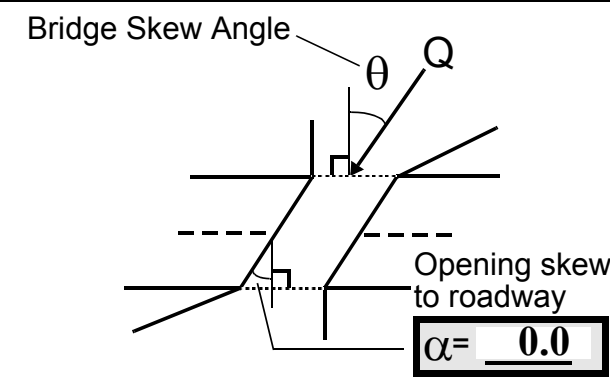

Exist? $\underline{\mathbf{Y}}(\mathrm{Y}$ or $N)$

Severity 1

, UB, DS) to $\underline{\mathbf{5}}$ feet $\underline{\mathbf{D S}}$

Exist? $\mathbf{Y}(\mathrm{Y}$ or $N)$

Severity 1 
18. Bridge Type: 4

1a- Vertical abutments with wingwalls

1 b- Vertical abutments without wingwalls

2- Vertical abutments and wingwalls, sloping embankment Wingwalls perpendicular to abut. face

3- Spill through abutments

4- Sloping embankment, vertical wingwalls and abutments
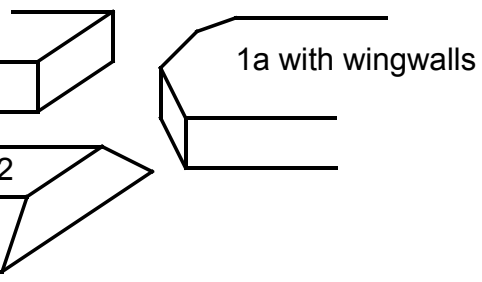

Wingwall angle less than $90^{\circ}$.

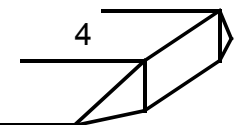

19. Bridge Deck Comments (surface cover variations, measured bridge and span lengths, bridge type variations, approach overflow width, etc.)

4. The left bank US surface cover is pasture within 1 bridge length and then it is forest beyond.

7. Values are from the VTAOT files. Measured bridge length between the backs of the abutments is $31.8 \mathrm{ft}$. US and $31.7 \mathrm{ft}$. DS. Span length between the abutment faces is $28.9 \mathrm{ft}$. US and $29.1 \mathrm{ft}$. DS, and bridge width is $27.8 \mathrm{ft}$. between the insides of the bridge rails and $29.2 \mathrm{ft}$. between the outsides of the deck.

17. The second impact zone is caused by a gradual channel bend to the left.

18. The wingwalls are vertical to about 2 ft. below low chord.

\section{Upstream Channel Assessment}

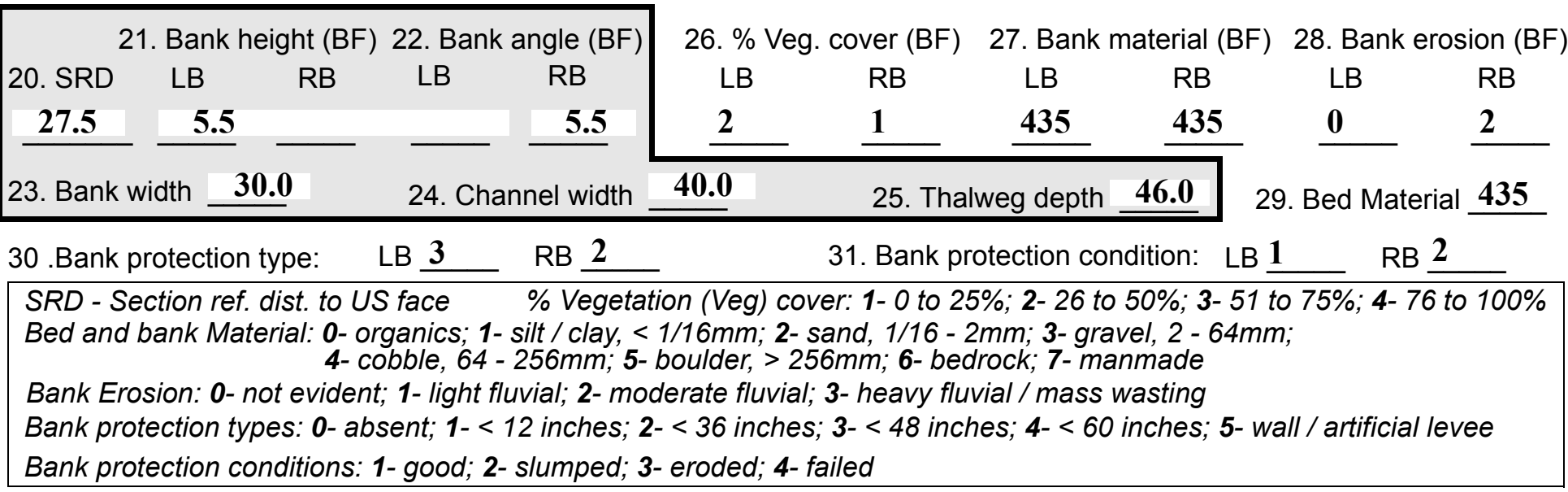

32. Comments (bank material variation, minor inflows, protection extent, etc.):

26. On the left bank there is no vegetation cover to $43 \mathrm{ft}$. US then it is $100 \%$ cover. On the right bank there is minor vegetation to $70 \mathrm{ft}$. US and then $75 \%$ cover.

27. Bank materials listed are found US of the protection.

28. Erosion on the right bank is from $13 \mathrm{ft}$. US to $200 \mathrm{ft}$. US. There is a cut bank and some slumping of the bank. On the left bank there is no evident erosion up to $110 \mathrm{ft}$. US.

30. Protection on both banks extends from $2 \mathrm{ft}$. US to $50 \mathrm{ft}$. US.

31. From $13 \mathrm{ft}$. US to $50 \mathrm{ft}$. US, the protection has been under cut on the right bank and has slumped into the channel.

The channel bends 90 degrees at $200 \mathrm{ft}$. US and is split about $250 \mathrm{ft}$. US and rejoins at $100 \mathrm{ft}$. US. The outside channel has cut into the left bank from $240 \mathrm{ft}$. US to $170 \mathrm{ft}$. US. Large stone fill (type 3) has been dumped along the impact zone. 
36. Point bar extent: 60 feet US (US, UB) to 35 feet $\underline{\text { DS }}$ (US, UB, DS) positioned $\mathbf{0}$ $\%$ LB to 60 $\% R B$

37. Material: $\mathbf{4 3 5}$

38. Point or side bar comments (Circle Point or Side; Note additional bars, material variation, status, etc.):

$-$

39. Is a cut-bank present? $\mathbf{Y}$ ( $Y$ or if $N$ type ctrl-n $c b)$

40. Where? $\underline{\mathbf{R B}}$ (LB or RB)

41. Mid-bank distance: $\mathbf{3 0}$

42. Cut bank extent: 13

43. Bank damage: 1

(1- eroded and/or creep; 2- slip failure; 3- block failure)

44. Cut bank comments (eg. additional cut banks, protection condition, etc.):

See comments under 32.

45. Is channel scour present? $\mathbf{N}$ (Y or if $N$ type ctrl-n cs)

47. Scour dimensions: Length Width -

Depth :-

46. Mid-scour distance: -

48. Scour comments (eg. additional scour areas, local scouring process, etc.):

\section{NO CHANNEL SCOUR}

Local scour at stone fill US on the left bank.

49. Are there major confluences? $\mathbf{N}$

51. Confluence 1: Distance -

Confluence 2: Distance -

54. Confluence comments (eg. confluence name):

NO MAJOR CONFLUENCES
(Y or if $N$ type ctrl-n $m c)$

52. Enters on -

Enters on ( $L B$ or $R B)$ (LB or $R B)$
50. How many? -

53. Type(1- perennial; 2- ephemeral)

Type (1-perennial; 2- ephemeral)

\section{NO MAJOR CONFLUENCES}

\section{Under Bridge Channel Assessment}

55. Channel restraint (BF)? LB 2

56. Height (BF)
LB RB
$\mathbf{3 0 . 5}$
58. Bank width (BF) -
59. Channel width (Amb) (1- natural bank; 2- abutment; 3- artificial levee)

Bed and bank Material: 0- organics; 1- silt / clay, < 1/16mm; 2- sand, 1/16 - 2mm; 3- gravel, 2 - 64mm; 4- cobble, 64 - 256mm; 5- boulder, > 256mm; 6- bedrock; 7- manmade

Bank Erosion: 0- not evident; 1- light fluvial; 2- moderate fluvial; 3- heavy fluvial / mass wasting

64. Comments (bank material variation, minor inflows, protection extent, etc.):

342

63. The type 3 placed protection in the channel along the right abutment is not included in the bed material. 
65. Debris and Ice Is there debris accumulation?

67. Debris Potential $\underline{1}$ (1- Low; 2- Moderate; 3- High)

69. Is there evidence of ice build-up? 1

70. Debris and Ice Comments:

1

The debris accumulation is small.

\section{The debri}

$(Y$ or $N)$ 66. Where? $\mathbf{Y}$

68. Capture Efficiency 2

(1- Upstream; 2- At bridge; 3-Both)

Ice Blockage Potential $\mathbf{N}$
(1-Low; 2- Moderate; 3- High)

(1-Low; 2- Moderate; 3- High)

\begin{tabular}{|l|c|c|c|c|c|c|c|c|}
\hline Abutments & $\begin{array}{c}\text { 71. Attack } \\
\angle \text { (BF) }\end{array}$ & $\begin{array}{c}\text { 72. Slope } \angle \\
\text { (Qmax) }\end{array}$ & $\begin{array}{c}\text { 73. Toe } \\
\text { loc. (BF) }\end{array}$ & $\begin{array}{c}\text { 74. Scour } \\
\text { Condition }\end{array}$ & $\begin{array}{c}75 . \text { Scour } \\
\text { depth }\end{array}$ & $\begin{array}{c}\text { 76. Exposure } \\
\text { depth }\end{array}$ & 77. Material & 78. Length \\
\hline LABUT & & $\mathbf{0}$ & $\mathbf{9 0}$ & $\mathbf{2}$ & $\mathbf{0}$ & - & - & $\mathbf{9 0 . 0}$ \\
\hline RABUT & $\mathbf{1}$ & $\mathbf{1 0}$ & $\mathbf{9 0}$ & & & $\mathbf{2}$ & $\mathbf{0}$ & $\mathbf{2 8 . 0}$ \\
\hline
\end{tabular}

Pushed: $L B$ or RB

Toe Location (Loc.): 0- even, 1- set back, 2- protrudes

Scour cond.: 0- not evident; 1- evident (comment); 2- footing exposed; 3-undermined footing; 4- piling exposed; 5- settled; 6- failed

Materials: 1- Concrete; 2- Stone masonry or drywall; 3- steel or metal; 4- wood

79. Abutment comments (eg. undermined penetration, unusual scour processes, debris, etc.):

$-$

1

74. The channel runs along the right abutment, thus the ambient water is deeper along this abutment. However, the type 3 protection of flat slabs of rocks placed in the channel along the abutment have prevented scour from occurring.

80. Wingwalls:

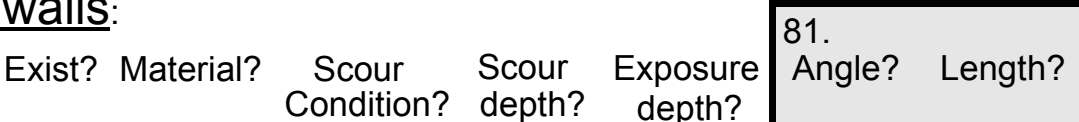

USLWW:

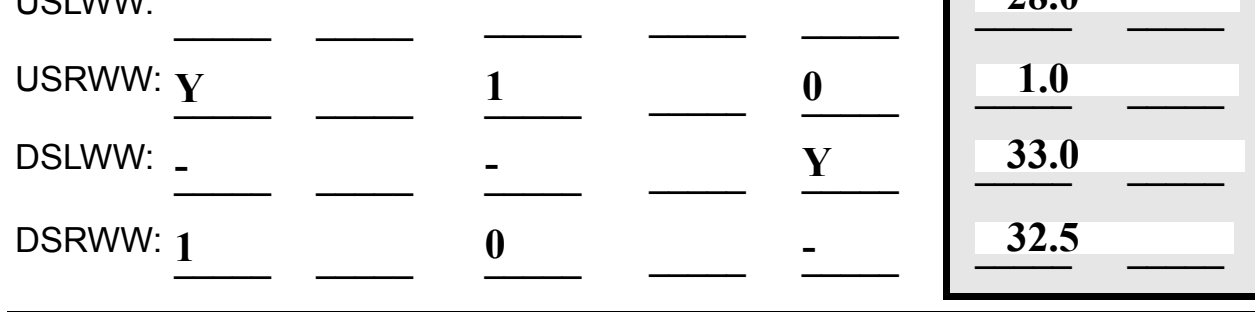

Wingwall materials: 1- Concrete; 2- Stone masonry or drywall; 3- steel or metal; 4- wood

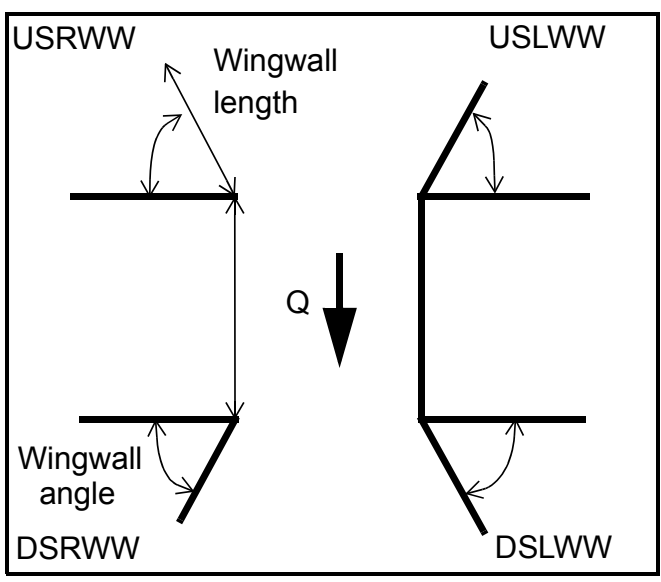

82. Bank / Bridge Protection:

\begin{tabular}{|l|l|l|l|l|l|l|l|l|}
\hline Location & USLWW & USRWW & LABUT & RABUT & LB & RB & DSLWW & DSRWW \\
\hline Type & - & $\mathbf{0}$ & $\mathbf{Y}$ & - & $\mathbf{1}$ & $\mathbf{1}$ & - & $\mathbf{1}$ \\
\hline Condition & $\mathbf{Y}$ & - & $\mathbf{1}$ & - & $\mathbf{1}$ & $\mathbf{1}$ & - & $\mathbf{1}$ \\
\hline Extent & $\mathbf{1}$ & - & $\mathbf{0}$ & $\mathbf{2}$ & $\mathbf{2}$ & $\mathbf{0}$ & $\mathbf{3}$ & - \\
\hline
\end{tabular}

Bank / Bridge protection types: 0- absent; 1- < 12 inches; 2- < 36 inches; 3- < 48 inches; 4- < 60 inches; 
83. Wingwall and protection comments (eg. undermined penetration, unusual scour processes, etc.):

-
-
-
-
-
3
1
1
3
1
1

\section{Piers:}

84. Are there piers? _ _ (Y or if $N$ type ctrl-n pr)

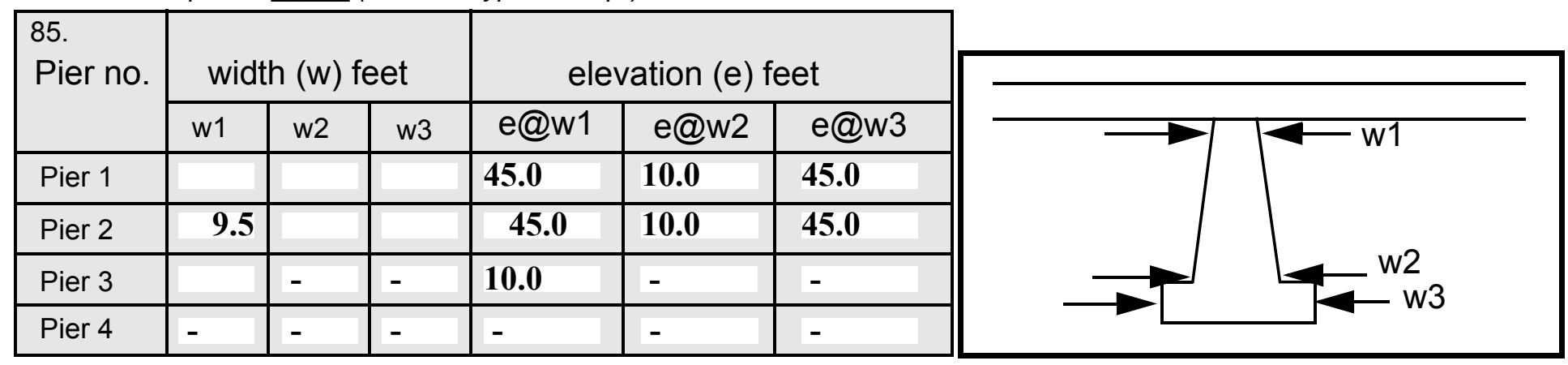

\begin{tabular}{|c|c|c|c|c|}
\hline Level 1 Pier Descr. & 1 & 2 & 3 & 4 \\
\hline 86. Location (BF) & & - & - & - \\
\hline 87. Type & & - & - & - \\
\hline 88. Material & & - & - & - \\
\hline 89. Shape & & - & - & - \\
\hline 90. Inclined? & & - & - & - \\
\hline 91. Attack $\angle(B F)$ & & - & - & - \\
\hline 92. Pushed & & - & - & - \\
\hline 93. Length (feet) & - & - & - & - \\
\hline 94. \# of piles & & - & - & - \\
\hline 95. Cross-members & & - & - & - \\
\hline 96. Scour Condition & & - & - & - \\
\hline 97. Scour depth & $\mathbf{N}$ & - & - & - \\
\hline 98. Exposure depth & - & - & - & - \\
\hline
\end{tabular}

LFP, LTB, LB, MCL, MCM, MCR, RB, RTB, RFP

1- Solid pier, 2- column, 3- bent

1-Wood; 2- concrete; 3- metal; 4- stone

1- Round; 2- Square; 3- Pointed

Y-yes; $N-$ no

$L B$ or $R B$

0- none; 1- laterals; 2- diagonals; 3- both

0- not evident; 1- evident (comment);

2- footing exposed; 3- piling exposed;

4- undermined footing; 5- settled; 6- failed 
99. Pier comments (eg. undermined penetration, protection and protection extent, unusual scour processes, etc.):

-
-
-
-
-
-
-
-
-
-

100.

\section{E. Downstream Channel Assessment}

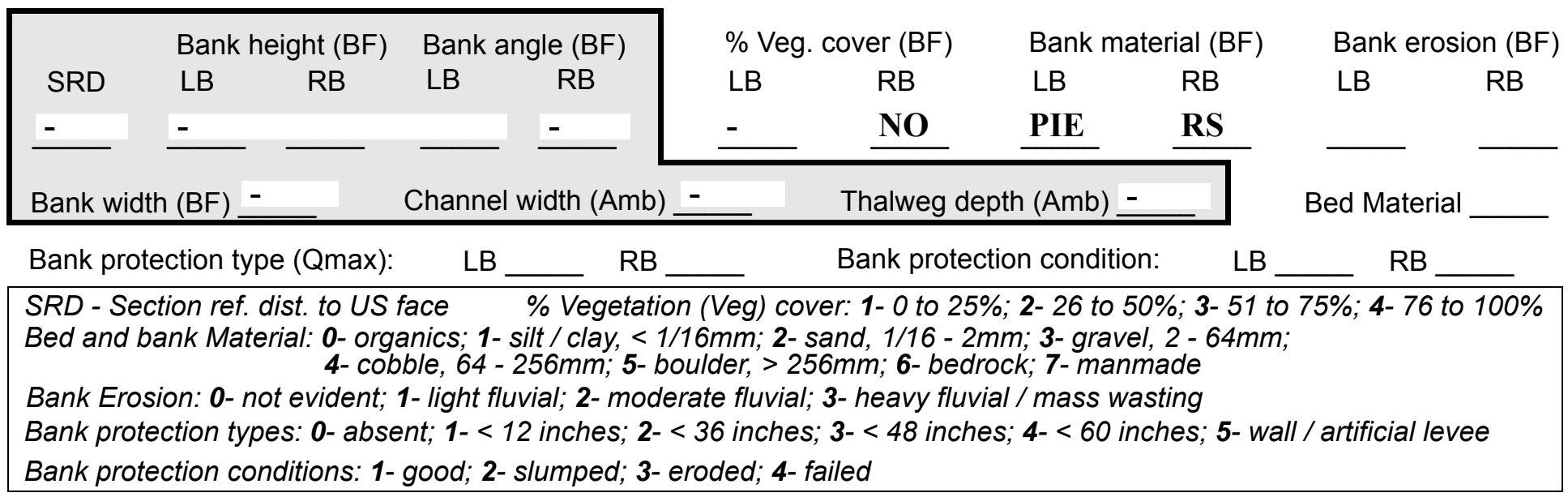

Comments (eg. bank material variation, minor inflows, protection extent, etc.):

3
2
435
435
0
2
435
3
3
1
1

On both banks, the bank protection is from $2 \mathrm{ft}$. DS to $20 \mathrm{ft}$. DS.

The right bank erosion is on the outside of the bend in the channel from $40 \mathrm{ft}$. DS to $200 \mathrm{ft}$. DS.

101. Is a drop structure present? $\mathbf{T}$ ( $Y$ or $N$, if $N$ type ctrl-n ds) 102. Distance: ___ feet

103. Drop: -_ feet 104. Structure material: he (1- steel sheet pile; 2- wood pile; 3- concrete; 4- other) 105. Drop structure comments (eg. downstream scour depth):

vegetation cover on the right bank is $0 \%$ to $30 \mathrm{ft}$. DS then $100 \%$. On the left bank it is also $0 \%$ next to the bridge to $20 \mathrm{ft}$. DS and then $75 \%$.

The channel bends towards the left bank to about $230 \mathrm{ft}$. DS then it makes a 90 degree bend to the left. 
Point bar extent: feet

(US, UB, DS) to feet (US, UB, DS) positioned $\underline{\mathbf{N}}$ $\%$ LB to $\%$ RB

Material: NO

Point or side bar comments (Circle Point or Side; note additional bars, material variation, status, etc.):

\section{DROP STRUCTURE}

Is a cut-bank present? ( $Y$ or if $N$ type ctrl-n $c b) \quad$ Where? (LB or $R B)$

Mid-bank distance: $\underline{\mathbf{Y}}$ Cut bank extent: 150 feet 15 (US, UB, DS) to 105 feet $\underline{\text { DS }}$ (US, UB, DS)

Bank damage: 250 (1- eroded and/or creep; 2- slip failure; 3- block failure)

Cut bank comments (eg. additional cut banks, protection condition, etc.): $+$

DS

0

50

Is channel scour present? $\mathbf{3 4 5}$ ( $Y$ or if $N$ type ctrl-n cs) Mid-scour distance: The Scour dimensions: Length bar Width con- Depth: tinu Positioned es \% Scour comments (eg. additional scour areas, local scouring process, etc.): ond the 90 degree bend.

Are there major confluences? $\mathbf{Y}$ ( $Y$ or if $N$ type ctrl-n $m c)$

Confluence 1: Distance $\underline{\mathbf{1 0 0}}$

Confluence 2: Distance 115

Confluence comments (eg. confluence name):
How many? $\underline{\mathbf{R B}}$

Type DS (1- perennial; 2- ephemeral)

Type 1 (1- perennial; 2- ephemeral)

\section{F. Geomorphic Channel Assessment}

107. Stage of reach evolution

1- Constructed

2- Stable

3- Aggraded

4- Degraded

5- Laterally unstable

6- Vertically and laterally unstable 
108. Evolution comments (Channel evolution not considering bridge effects; See HEC-20, Figure 1 for geomorphic descriptors):

$\mathbf{N}$

$-$

$-$

$-$

$-$

$-$

NO CHANNEL SCOUR

Y 


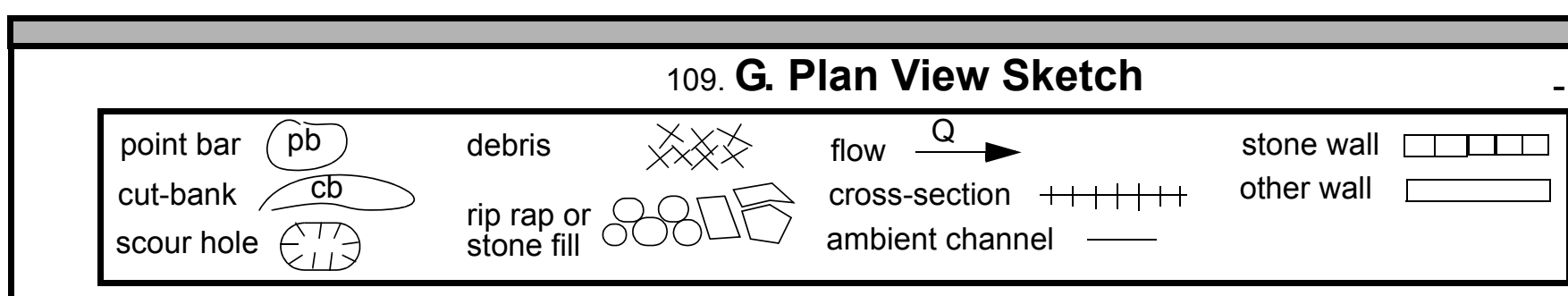

cut-bank $\mathrm{cb}$

scour hole rip rap or stone fill $000 \mathrm{~L}$ cross-section $+1+1+1$ ambient channe other wall 
APPENDIX F:

SCOUR COMPUTATIONS 


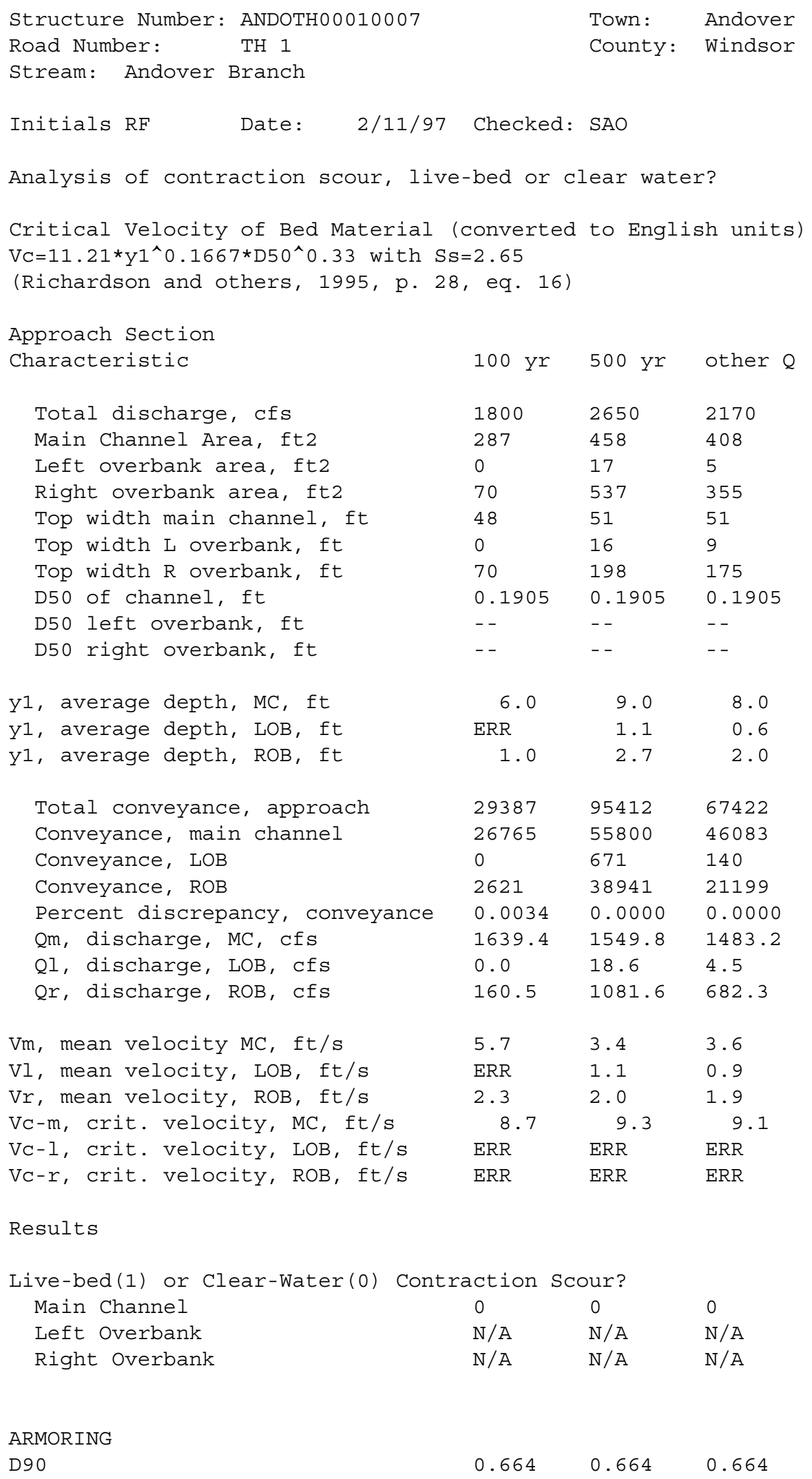


D95

Critical grain size, Dc, ft Decimal-percent coarser than DC Depth to armoring, ft

$\begin{array}{lll}0.941 & 0.941 & 0.941 \\ 0.7956 & 0.4033 & 0.3015 \\ 0.07436 & 0.18744 & 0.27692 \\ 29.71 & 5.25 & 2.36\end{array}$

Clear water Contraction Scour in MAIN CHANNEL

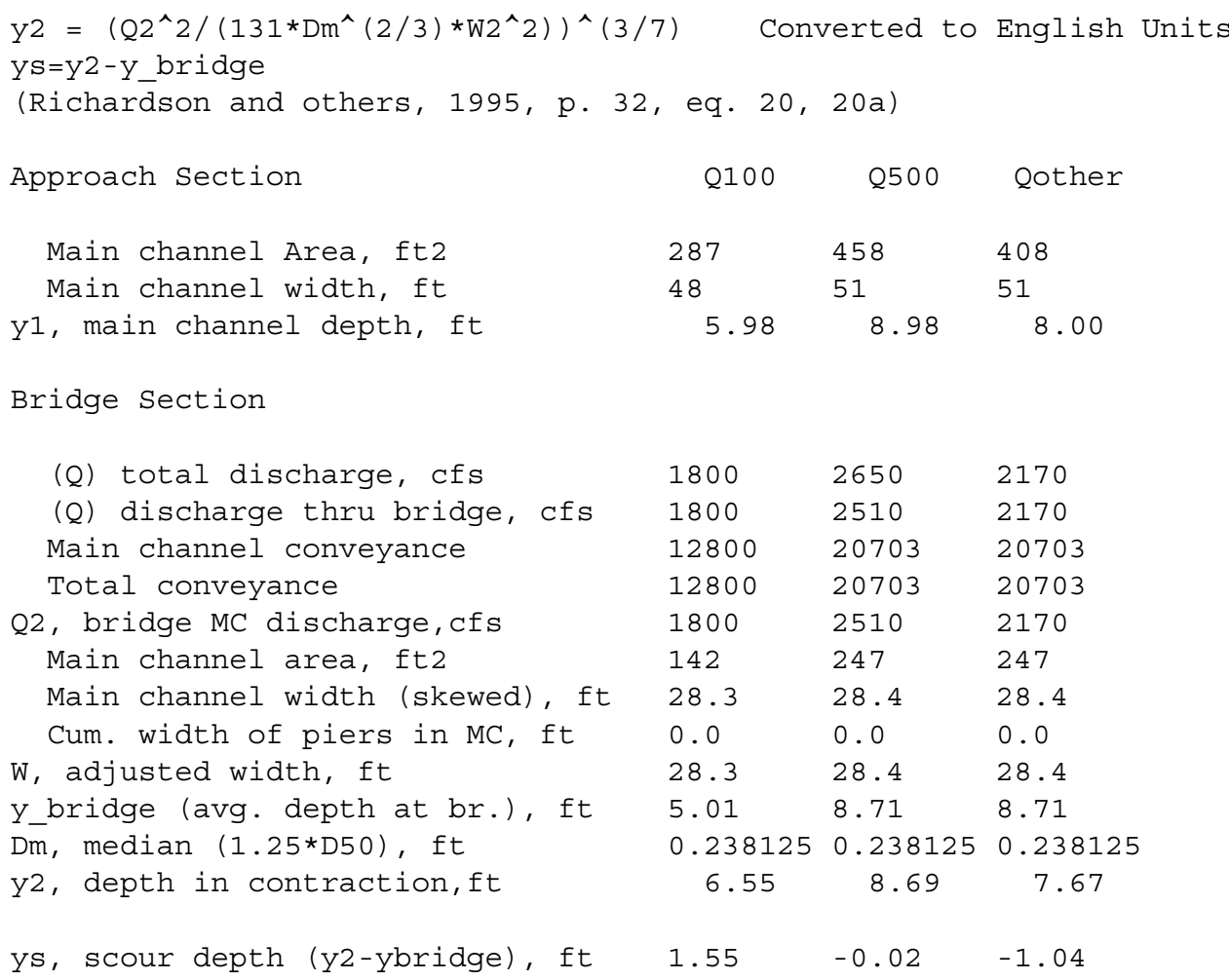




\begin{tabular}{|c|c|c|c|}
\hline $\mathrm{Hb}$, depth of full opening, ft & 5.01 & 8.71 & 8.71 \\
\hline Hb, depth of full opening, m & 1.53 & 2.65 & 2.65 \\
\hline Fr, Froude number, bridge MC & 0 & 0.61 & 0.52 \\
\hline Cf, Fr correction factor $(<=1.0)$ & 0.00 & 1.00 & 1.00 \\
\hline Elevation of Low steel, ft & 0 & 497.89 & 497.89 \\
\hline Elevation of Bed, ft & -5.01 & 489.18 & 489.18 \\
\hline Elevation of Approach, ft & 0 & 500.6 & 499.63 \\
\hline Friction loss, approach, ft & 0 & 0.1 & 0.09 \\
\hline Elevation of WS immediately US, ft & 0.00 & 500.50 & 499.54 \\
\hline ya, depth immediately US, ft & 5.01 & 11.32 & 10.36 \\
\hline ya, depth immediately US, m & 1.53 & 3.45 & 3.16 \\
\hline Mean elevation of deck, ft & 0 & 500.203 & 500.203 \\
\hline w, depth of overflow, ft $(>=0)$ & 0.00 & 0.30 & 0.00 \\
\hline Cc, vert contrac correction $(<=1.0)$ & 1.00 & 0.94 & 0.96 \\
\hline Ys, depth of scour, ft & $\mathrm{N} / \mathrm{A}$ & 1.38 & 0.04 \\
\hline omparison of Chang and Laursen res & dits (for & unsubmerg & yed orifice flon \\
\hline y2, from Laursen's equation, ft & 6.553887 & 8.688771 & 7.669639 \\
\hline Full valley WSEL, ft & & 495.87 & 495.23 \\
\hline Full valley depth, ft & ERR & 6.687746 & 6.047746 \\
\hline Ys, depth of scour (y2-yfullv), ft & $\mathrm{N} / \mathrm{A}$ & 2.001024 & 1.621893 \\
\hline
\end{tabular}

Abutment Scour

Froehlich's Abutment Scour

$\mathrm{Ys} / \mathrm{Y} 1=2.27 * \mathrm{~K} 1 * \mathrm{~K} 2 *\left(\mathrm{a}^{\prime} / \mathrm{Y} 1\right)^{\wedge} 0.43 * \mathrm{Fr} 1^{\wedge} 0.61+1$

(Richardson and others, 1995, p. 48, eq. 28)

Characteristic

Left Abutment
$100 \mathrm{yr}$ Q $500 \mathrm{yr} Q$ Other Q $100 \mathrm{yr} Q 500 \mathrm{yr} Q$ Other Q

Left Abutment
$100 \mathrm{yr}$ Q $500 \mathrm{yr} Q$ Other Q $100 \mathrm{yr} Q 500 \mathrm{yr} Q$ Other Q

\begin{tabular}{|c|c|c|c|c|c|c|}
\hline (Qt), total discharge, cfs & 1800 & 2650 & 2170 & 1800 & 2650 & 2170 \\
\hline a', abut.length blocking flow, & 10.7 & 29.7 & 22.7 & 79.2 & 206.6 & 184.2 \\
\hline Ae, area of blocked flow ft 2 & 29.9 & 74.75 & 66.73 & 119.45 & 614.1 & 426.08 \\
\hline Qe, discharge blocked abut., cfs & 92.9 & & 148.87 & 402.35 & & 915.74 \\
\hline (If using Qtotal_overbank to obta & in Ve, & leave Qe & blank and & enter $\mathrm{Ve}$ & and Fr & all \\
\hline Ve, $(\mathrm{Qe} / \mathrm{Ae}), \mathrm{ft} / \mathrm{s}^{-}$ & 3.11 & 2.12 & 2.23 & 3.37 & 2.15 & 2.15 \\
\hline ya, depth of $\mathrm{f} / \mathrm{p}$ flow, ft & 2.79 & 2.52 & 2.94 & 1.51 & 2.97 & 2.31 \\
\hline
\end{tabular}

--Coeff., K1, for abut. type (1.0, verti.; 0.82, verti. w/ wingwall; 0.55, spillthru)

$\begin{array}{lllllll}\text { K1 } & 0.82 & 0.82 & 0.82 & 0.82 & 0.82 & 0.82\end{array}$

--Angle (theta) of embankment (<90 if abut. points DS; >90 if abut. points US)

\begin{tabular}{|c|c|c|c|c|c|c|}
\hline theta & 90 & 90 & 90 & 90 & 90 & 90 \\
\hline $\mathrm{K} 2$ & 1.00 & 1.00 & 1.00 & 1.00 & 1.00 & 1.00 \\
\hline Fr, froude number $\mathrm{f} / \mathrm{p}$ flow & 0.328 & 0.211 & 0.229 & 0.483 & 0.219 & 0.249 \\
\hline scour depth, ft & 7.48 & 7.76 & 8.31 & 11.40 & 16.55 & 14.43 \\
\hline
\end{tabular}

HIRE equation (a'/ya > 25)

$\mathrm{ys}=4 * \mathrm{Fr}^{\wedge} 0.33 * \mathrm{Y} 1 * \mathrm{~K} / 0.55$

(Richardson and others, 1995, p. 49, eq. 29)

$\mathrm{a}^{\prime}$ (abut length blocked, ft)

$\begin{array}{llllll}10.7 & 29.7 & 22.7 & 79.2 & 206.6 & 184.2\end{array}$

y1 (depth $f / p$ flow, ft)

2.79

2.52

2.94

1.51

2.97

2.31 


\begin{tabular}{|c|c|c|c|c|c|c|}
\hline$a^{\prime} / y 1$ & 3.83 & 11.80 & 7.72 & 52.51 & 69.51 & 79.63 \\
\hline Skew correction (p. 49, fig. 16) & 1.00 & 1.00 & 1.00 & 1.00 & 1.00 & 1.00 \\
\hline Froude no. f/p flow & 0.33 & 0.21 & 0.23 & 0.48 & 0.22 & 0.25 \\
\hline Ys w/ corr. factor K1/0.55: & FRR & FRR & $E R R$ & 8.63 & 13.10 & 10.63 \\
\hline vertical w/ $\mathrm{ww}^{\prime} \mathrm{s}$ & ERR & ERR & $\mathrm{ERR}$ & 7.08 & 10.74 & 8.72 \\
\hline spill-through & ERR & ERR & ERR & 4.75 & 7.20 & 5.85 \\
\hline Abutment riprap Sizing & & & & & & \\
\hline Isbash Relationship & & & & & & \\
\hline $\mathrm{D} 50=\mathrm{Y}^{*} \mathrm{~K} * \mathrm{Fr}{ }^{\wedge} 2 /(\mathrm{Ss}-1)$ and $\mathrm{D} 50=\mathrm{Y}^{*} \mathrm{~K} *(\mathrm{Fr}$ & $\wedge 2) \wedge 0$. & $(\mathrm{SS}-1)$ & & & & \\
\hline (Richardson and others, 1995, p112, & eq. 8 & & & & & \\
\hline Characteristic & Q100 & Q500 & Qother & Q100 & Q500 & Qother \\
\hline Fr, Froude Number & 1 & 0.61 & 0.52 & 1 & 0.61 & 0.52 \\
\hline (Fr from the characteristic $V$ and & $y$ in & tractec & section- & ne, bri & secti & \\
\hline$y$, depth of flow in bridge, ft & 5.01 & 8.71 & 8.71 & 5.01 & 8.71 & 8.71 \\
\hline Median Stone Diameter for riprap at & : left & utment & & right & butment & ft \\
\hline Fr<=0.8 (vertical abut.) & ERR & 2.00 & 1.46 & ERR & 2.00 & 1.46 \\
\hline Fr>0.8 (vertical abut.) & 2.09 & ERR & ERR & 2.09 & ERR & ERR \\
\hline Fr<=0.8 (spillthrough abut.) & ERR & 1.75 & 1.27 & $\mathrm{ERR}$ & 1.75 & 1.27 \\
\hline Fr>0.8 (spillthrough abut.) & 1.85 & ERR & ERR & 1.85 & ERR & ERR \\
\hline
\end{tabular}

